\title{
Do Opposites Attract? \\ Dissimilar Directors and Coordination within Corporate Boards*
}

\author{
Anzhela Knyazeva ${ }^{\dagger}$ \\ Diana Knyazeva \\ Charu Raheja
}

First version: January, 2009

This version: December, 2012

\begin{abstract}
We investigate the implications of dispersion in individual director characteristics within a corporate board for shareholder value. The presence of directors with dissimilar skill sets can augment the board's overall information set and increase the flexibility and effectiveness of the board's decision making. At the same time, greater variety of director characteristics within a board can raise coordination costs and adversely affect board functions. We find a negative relation between dispersion in director expertise and incentives within a board and firm value. Further, dispersion in director characteristics is associated with lower CEO incentive pay, higher cash and overall pay, lower cash holdings and investment spending, higher leverage, and higher dividends. To address causality concerns, we exploit external constraints that prompt firms to hire dissimilar directors. We also conduct an event study of M\&A announcements and examine market reaction to changes in dispersion due to director appointments, departures and deaths.
\end{abstract}

JEL classification: G30, G34

Keywords: boards, directors, monitoring, coordination problems, shareholder value

\footnotetext{
* We thank Anup Agrawal Mark Chen, Daniel Ferreira, Shane Heitzman, Kose John, Jonathan Karpoff, John Long, Sanjog Misra, Shawn Mobbs, Robert Nash, Bruce Resnick, Bill Schwert, Cliff Smith, Jerry Warner, Toni Whited, seminar participants at the University of Alabama, studentseminar participants at the University of Washington, and conference participants at the American Finance Association (2010), Financial Economics and Accounting (2009), and Financial Management Association (2009) meetings for helpful suggestions.

$\dagger$ Corresponding author. Address: University of Rochester, Simon School of Business, Box 270100, Rochester, NY 14627. E-mail: anzhela.knyazeva@simon.rochester.edu. Phone: 585-275-3102.
} 


\section{Introduction}

A corporate board of directors performs critical functions of monitoring and advising top management. Board members make decisions as a group, which gives rise to issues of efficiency in the board's operating process and group dynamics within a board. Jensen (1993) argues that although a board requires breadth of knowledge for strategic planning and monitoring, coordination problems within a board decrease its effectiveness. An important yet largely overlooked issue that affects a board's ability to perform advisory and monitoring roles in a coordinated manner is the presence of dissimilar directors on the board. Rather than consider incentives or conflicts of interest of the board as a whole, which is a common theme in existing work, we study the implications of dispersion in director expertise and incentives within a board for firm outcomes.

Diversity within corporate boards has been the subject of several recent attempts to improve board effectiveness. Some institutional investors have offered specific recommendations regarding board diversity. For example, CalPERS advises in its best governance practices statement that "...the board should consist of directors with the requisite range of skills, competence, knowledge, experience and approach, as well as a diversity of perspectives... to

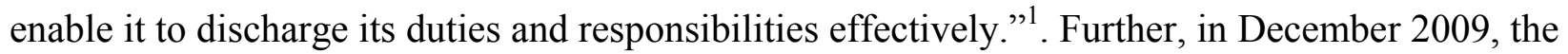
SEC released new proxy rules that mandate disclosure of diversity in director nominations ${ }^{2}$ and point to several dimensions of director diversity, such as "viewpoint, professional experience, education, skill and other individual qualities and attributes.” Recently, Facebook has been looking to diversify the composition of its board: "Once Facebook becomes a public company,

\footnotetext{
${ }^{1}$ CalPERS, Global Principles of Accountable Corporate Governance, http://www.calpers-governance.org/docssof/principles/2010-5-2-global-principles-of-accountable-corp-gov.pdf.

${ }^{2}$ Securities and Exchange Commission, "SEC approves enhanced disclosure about risk, compensation and corporate governance,” December 16, 2009, http://www.sec.gov/news/press/2009/2009-268.htm.
} 
the board needs a seasoned corporate director and people with a variety of backgrounds...The board shouldn't be a rubber stamp for Zuckerberg."3

Prior work has emphasized the roles of the board as a whole in monitoring and advising top management (e.g., Hermalin and Weisbach (1998), Raheja (2005), Harris and Raviv (2008), Adams and Ferreira (2007), Masulis and Mobbs (2011)). Despite a large literature on corporate boards, the understanding of dynamics of director interactions within a board is limited. As Adams et al. (2010) points out, the board is typically modeled as a single decision maker, without consideration for group dynamics. A few recent papers examine women on boards (Ahern and Dittmar (2012), Adams and Ferreira (2009)). Carter et al. (2003) find positive effects of gender and ethnic diversity on firm value. Differently from the above papers, we consider director-level differences in expertise and incentives, rather than demographics, within a corporate board. In a contemporaneous paper, Anderson et al. (2011) examine heterogeneity in director demographics, board seats, and educational backgrounds, and find positive effects on performance.

Our paper focuses on directors with dissimilar expertise and payoffs within a board, dimensions we believe to be most relevant for board advisory and monitoring tasks (relative to demographic parameters, such as gender and nationality, or general educational or executive background). Crucially, we find negative overall effects of the presence of dissimilar directors. Our empirical analysis tackles endogeneity issues that inevitably arise in board studies via a three-pronged approach: the use of instruments to capture constraints that drive dispersion in director characteristics within boards, the study of announcement effects of acquisitions, and the analysis of market reaction to announcements of director appointments, departures and deaths

3 Bloomberg, Facebook Said to Seek Directors Who Can Add Diversity to Board, May 15, 2012, http://www.bloomberg.com/news/2012-05-15/facebook-said-to-seek-directors-who-can-add-diversity-to-board.html. 
affecting within-board variation in director characteristics. Our study provides novel evidence on the implications of the presence of dissimilar directors on boards for shareholders, and more generally, sheds light on the broader issue of board dynamics and director interactions within a board.

Conceptually, the presence of dissimilar directors on a board presents a tradeoff. On the one hand, it can increase coordination costs, which hamper the board's ability to effectively exercise advisory and monitoring functions, resulting in value destruction. On the other hand, the presence of within-board variation in director knowledge and skill sets can result in greater breadth of the board's collective information set and improved ability to advise management. Economic research on group diversity suggests that the nature of tasks performed by the group matters for the analysis of costs and benefits of diversity (see, e.g., Cornes (1993), Vigdor (2004), Ledyard (1995), and Hamilton et al. (2003)). Benefits of diversity might be greatest for tasks involving group information production whereas costs of diversity could be highest for tasks that require coordination among group members towards a specified goal (Page (2007)). Our analysis considers the tradeoff between information production and coordination in the context of corporate board decision-making.

While diversity in director attributes can be characterized using a number of dimensions, we focus on within-board variation in the areas of knowledge, experience and incentives of directors on each board. Specifically, we consider within-board differences in the types of director expertise, board appointments, and director ownership. For robustness we also use diversity in other director characteristics, such as director tenure with the firm.

Our main findings are as follows. Holding other factors constant, the presence of dissimilar directors on a board is associated with lower firm value. Importantly, although various 
board characteristics are interrelated, the effect of dispersion in director characteristics on value is not explained by other board characteristics, including board independence, size, and average board expertise or ownership levels. Besides including a number of controls to mitigate omitted variable bias, we address potential endogeneity in several ways. We use external constraints, such as industry factors, regional characteristics, limited local availability of qualified directors, and compliance with more stringent board independence requirements, to predict the presence of dissimilar directors on corporate boards and find similar value effects in a two-stage setting. Further, we examine the effect of dispersion in director characteristics on the market reaction to the announcement of major value-relevant corporate decisions and board changes that affect the level of within-board variation in director characteristics. Consistent with firm value findings, boards with dissimilar directors have a negative effect on the shareholder reaction to acquisition announcements. Finally, we find that shareholders of growth firms react more adversely to the increase in dispersion in director characteristics.

The presence of dissimilar directors on boards is also systematically related to crucial firm decisions. They are associated with a lower fraction of incentive pay in total CEO pay. Given that incentive pay improves managerial alignment and firm value (e.g., Mehran (1995)), this finding is consistent with coordination problems preventing such boards from establishing effective incentives that align the CEO with shareholder interests. Further, all else equal, the dissimilar directors on the board are associated with lower investment, lower cash holdings, and higher debt and dividend levels. Given the arguments in Jensen (1986) and the evidence in John et al. (2011) on the use of financial commitments to mitigate agency problems and governance shortcomings, the results are consistent with the notion that such boards are not able to resolve 
conflicts of interest through direct CEO oversight or incentive pay, so they resort to costly financial commitments to curtail agency problems.

The remainder of the paper is organized as follows. The second section discusses related work and our paper's contribution and formulates testable predictions and measures of dispersion within boards. The third section presents the main empirical results and robustness tests. The fourth section concludes.

\section{Variation in director characteristics within a corporate board and firm value}

Our analysis of variation in director attributes within a board focuses on differences in director expertise (industry, size, risk, and lifecycle expertise), overall reputation and experience (measured by the number of board appointments), and ownership incentives. We focus on these dimensions because they capture director incentives and skills, which are most directly associated with director ability to effectively perform managerial oversight and other board duties. We develop our main hypotheses below.

\subsection{Hypotheses}

Costs of dispersion in director expertise and incentives within a board

The presence of dissimilar directors on the board can increase coordination costs and decrease board members' ability to work together as a group, resulting in disagreement among directors about investment projects, acquisitions, and other key decisions, introducing inefficiencies in the decision making process.

Differences in director opinion and viewpoints resulting from the presence of directors with varying skill sets and backgrounds could slow down decision making and spur disagreement or even conflicts in the boardroom (see, e.g., the Baranchuk and Dybvig (2009) model of board consensus, where the presence of multiple director types with varying 
information sets results in disagreement and conflict). The resulting testable prediction is formulated below:

Boards composed of directors with dissimilar skill sets face more disagreement and are less effective at advising the CEO, resulting in a negative effect on firm value.

In addition to having varying skill sets, directors can differ in their incentives. Models of group decision making, group production, and public good provision identify costs of withingroup heterogeneity in incentives. For instance, collective action problems involving the provision of public goods are more severe in the presence of heterogeneous agents (see, e.g., Cornes (1993); Vigdor (2004); Bardhan (1993)). Within-group heterogeneity in payoffs increases free riding and decreases agents' incentives to cooperate. In the context of board decision making, Fluck and Khanna (2011) show that such coordination frictions in information collection and sharing and free riding among board members decrease the overall level of board monitoring and firm value. These models predict higher coordination costs and lower firm value in the presence of diverse director payoffs, yielding the following hypothesis:

Boards composed of directors with dissimilar payoffs face more collective action problems, resulting in weaker monitoring incentives and a negative effect on firm value.

Benefits of dispersion in director expertise and incentives

Alternatively, greater variation in director expertise and incentives within a board could yield substantial benefits. Group diversity literature (e.g., Page (2007) and Steiner (1966) among others) argues that the diversity tradeoff depends on the functions performed by the group. Presence of directors from different fields or industries contributes to the generation of ideas and breadth of knowledge of the board as a group, allowing the board to guide the CEO on a variety of corporate policies and projects. As diverse directors pool their skill sets and experience, the 
board's overall information set expands, resulting in an improved ability of the board as a whole to advise management. This benefit of the presence of dissimilar directors is formalized in models of team production, which show the benefits of heterogeneity in skills for the generation of new ideas and solutions (see, e.g., Alesina et al., 2000; Hamilton et al., 2003). Sibert (2003) suggests that diverse information sets can help improve aggregate forecasts, overall accuracy of the board's recommendations, and evaluation of investment decisions. Further, heterogeneity in payoffs can be optimal when the nature of the firm's operating structure calls for differential director roles in advising the CEO.

The presence of directors with dissimilar skill sets on the board increases the breadth of available information, resulting in an improved ability of the board as a whole to advise the CEO and a positive effect on firm value.

Greater variation in the payoffs of members of a given board can increase the likelihood that one or more directors have disproportionately stronger incentives, causing them to take charge and lead the board in the monitoring of the CEO. For example, Bergstrom, Blume, and Varian (1986) show that heterogeneity in wealth decreases free riding and increases agents' contribution to public goods. Kandel and Lazear (1992) similarly argue that heterogeneous groups are more likely to overcome collective action problems. The empirical prediction follows below:

The presence of directors with dissimilar payoffs on the board increases the likelihood that the CEO will face board oversight, resulting in a positive effect on firm value.

The question of which effect prevails is ultimately an empirical one. We develop our main measures below. 


\subsection{Measurement}

Table 1 contains definitions and summary statistics of the measures of within-board variation in director characteristics. Appendix A provides an example of construction of the measures of interest for a hypothetical firm.

\section{[Table 1]}

Dispersion in director expertise is measured as variation in the experience of individual board members in different industries or fields. We construct this measure based on director service on other boards as $1-\Sigma x_{i}^{2}$, where $x_{k}$ is the ratio of the number of directorships held by the sample firm's directors at firms of a particular type to the total number of directorships held by the sample firm's directors at other firms. Lower values of the measure indicate more focus in director expertise, whereas higher values indicate more dispersion in director experience. ${ }^{4}$ Our main measure focuses on variation in industry expertise (using the Fama-French classification). We also consider several other crucial dimensions of director expertise, such as experience in advising large versus small firms, experience at firms in different lifecycle phases, and risk expertise.

Next, we consider within-board variation in the number of board seats held by the firm's directors. Research suggests that the number of directorships held by a director affects both the director's overall experience and incentives to monitor (e.g., Yermack (2004); Fich and Shivdasani (2006), (2007)). Whether multiple directorships strengthen or weaken director

\footnotetext{
${ }^{4}$ Due to limits on the length of the governance series, we assess director expertise based on other appointments in a specific field, position, industry, or type of firm in the current year. This definition emphasizes contemporaneous experience. Also, for a meaningful interpretation, measures of heterogeneity in expertise are only constructed for boards whose directors as a group hold positions at two or more other firms with available data.

Further, the main measure assigns equal weight to all directorships in cases of directors holding multiple seats elsewhere. In a robustness check, we retain only one position that is most relevant for describing the director's expertise, giving preference to positions involving insider (employee) status, lead director role, longer tenure on the other firm's board, or position at a larger firm.
} 
incentives, within-firm heterogeneity in the number of board seats held by the firm's directors

captures dispersion in director incentives and/or experience. We construct the measure as $1-\Sigma d_{j}{ }^{2}$, where $d_{j}$ is the ratio of the number of directors with $j$ board seats to the total number of board members. Higher values indicate more dispersion among directors. A typical outside director holds seats on two or three boards.

Finally, we examine variation in director incentives within a board. A director's ownership stake in the firm impacts the incentive to gather information and monitor management. Heterogeneity in director ownership incentives is defined as $1-\Sigma s_{i}^{2}$, where $s_{i}$ is the share of director i's stake in the total board stake in the firm. (Scaling by the total board stake ensures that the measure filters out firm differences in overall board ownership incentives.) Higher values reflect more dispersion in director incentives. ${ }^{5}$

The sample is based on Board Analyst data for 2001-2006, merged with Compustat and Execucomp. We exclude small firms (total assets below \$20 million), firms incorporated abroad, financial firms (SIC 6000-6999), and regulated utilities (SIC 4900-4999).

\subsection{Univariate evidence}

Table 2 documents univariate relations between within-board variation in director characteristics and firm value. [Later in the paper we control for variation in growth opportunities to account for the alternative interpretation of market-to-book and use announcement returns as a different way of examining value implications.]

[Table 2]

\footnotetext{
${ }^{5}$ The last two measures use independent directors only. Inside directors have substantial human capital vested in the firm, so their incentives are disproportionately stronger than implied by their ownership stake or reputation gained from directorships.
} 
Tabulations of market-to-book ratios for the bottom $50 \%$ and top $50 \%$ of director dispersion (as well as the bottom and top quartiles) show a strong negative association between the presence of dissimilar directors and firm value. Without controlling for other factors, a move from the bottom quartile to the top quartile of within-board variation in director industry expertise, director ownership or number of board seats is associated with a decline in the marketto-book ratio by $0.53,0.47$, and 0.32 , respectively. The effects are not only highly significant, but also economically meaningful, amounting to between $19 \%$ and $32 \%$ of the sample standard deviation of market-to-book. A similar pattern emerges for measures of within-board differences based on other dimensions of director qualifications and overall expertise and incentives. Although the univariate results suggest a negative relation with firm value, they do not control for differences in other firm characteristics, so we turn next to the multivariate results.

\section{Empirical analysis}

\subsection{Main tests}

Table 3 presents multivariate analysis of the relation between within-board differences in director characteristics and firm value. The models regress firm value on our measures of dissimilarity in director characteristics and other explanatory variables. We control for the following common factors associated with firm value: firm maturity (measured by firm size and firm age), firm growth opportunities (measured by sales growth), cash flow (ratio of income before extraordinary items plus depreciation to total assets), tangible assets (share of property, plants and equipment in total assets), and CEO tenure in the firm. Year dummies and three-digit SIC industry effects are included in all tests to control for variation in industry and economic 
conditions. ${ }^{6}$ Consistent with prior research, size, cash flow, sales growth, and younger firm age are positively related to market-to-book. CEOs with longer tenure are on the margin associated with higher firm value, although we do not infer causality (the pattern is consistent with well performing CEOs being retained for a longer period).

[Table 3]

Holding other variables constant, both dispersion in director industry experience and dispersion in director incentives within a board have negative effects on firm value. A one standard deviation increase in the level of within-board dispersion in industry expertise is associated with a decrease in market-to-book ratio by $21 \%$ of a standard deviation of market-tobook, depending on the measure of diversity. A one standard deviation increase in the level of within-board dispersion in director ownership incentives is associated with a decrease in marketto-book ratio by approximately $11 \%$ of the sample standard deviation of market-to-book.

Panel B examines additional measures of dispersion in director experience and incentives discussed in the appendix. Columns I-III examine other dimensions of director expertise, including expertise in advising businesses characterized by different size, phase of the lifecycle, and operating risk. These additional proxies are highly correlated with our original measure of dispersion in director expertise, so they are included separately to avoid multicollinearity. Column IV uses an equal-weighted index of dispersion in the four types of expertise (industry, size, lifecycle, and risk). Column $\mathrm{V}$ uses an index of board dispersion that equally weights measures of within-board variation in director industry expertise, board seats, and ownership stakes from Panel A. Our main results continue to hold. The additional measures have significant

\footnotetext{
${ }^{6}$ Due to the sample period with available Board Analyst data (2001-2006) and exit and entry of firms from the sample, the presence of too few annual observations impairs our ability to consider within-firm variation.
} 
coefficients of comparable economic magnitude, ranging from $8 \%$ to $21 \%$ of a standard deviation of market-to-book.

Overall, multivariate analyses corroborate the negative relation between board dispersion and firm value, for the key dimensions of director characteristics, including director expertise, board seats, and ownership incentives. Although the evidence does not definitively establish causality, it is consistent with the hypothesis about the coordination problems arising from the presence of dissimilar directors.

\subsection{Robustness}

Additional controls and alternative explanations

Dispersion within boards could be proxying for other board characteristics, such as board size, proportion of independent directors, average director ownership in the firm, director busyness or average director tenure. First, we rule out the possibility that large boards or boards with busy directors, which have been linked to lower firm value (Yermack (1996); Fich and Shivdasani (2006)), explain the negative relation between dispersion in director characteristics within a board and firm value. In Panel A of Table 4 we exclude companies with large boards (ten or more directors on the board). In Panel B we eliminate firms with busy boards (average number of directorships per board member is three or greater). The results are similar to the findings of the main tests. The negative effect of within-board dispersion in director characteristics does not appear to be driven by large boards or boards with busy directors.

[Table 4]

Table 5 presents robustness tests that include several additional variables to the main specification. In Panel A we control for board size and board independence to address the possibility that the presence of dissimilar directors is proxying for agency conflicts of board 
insiders or ineffectiveness of large boards documented in prior work. Consistent with Yermack (1996), firm value is decreasing in board size. With other determinants already included in the model, board independence does not have a significant incremental effect. $^{7}$

Importantly, after controlling for board independence and size, the effect of within-board dispersion in director characteristics remains significant.

\section{[Table 5]}

In Panel B we incorporate several other characteristics that could be associated with the presence of dissimilar directors on the board as well as firm value, based on previous studies of board structure by Boone et al. (2007), Coles et al. (2008), and Linck et al. (2008). We control for business diversification, geographic diversification (foreign segment dummy), high tech indicator, and product market concentration. Firm value is negatively associated with business diversification, consistent with prior work on valuation discount for multi-segment firms. The remaining additional controls are not significant. Importantly, our finding of the negative relation between board diversity and firm value continues to hold.

In Panel $\mathrm{C}$, we examine several other measures of within-board dispersion in director characteristics described in the appendix: dispersion in director industry expertise based on the most influential board appointment outside the firm, rather than all board appointments; an equal-weighted index of six measures of dissimilar directors (within-board dispersion in director industry expertise, size expertise, risk expertise, lifecycle expertise, number of board seats, and ownership incentives) instead of individual measures; and dispersion in director tenure within a board, as an additional way of capturing divergence in firm-specific director human capital and

\footnotetext{
${ }^{7}$ Many other studies find mixed evidence on performance and value effects of director independence, for example, Yermack (1996), Bhagat and Black (2002), Klein (1998), and Agrawal and Knoeber (1996) (see Adams et al. (2010) for a survey).
} 
incentives within a board. As in the previous tests, we observe a significant negative relation between dispersion in director characteristics and firm valuation.

In the spirit of Coles et al. (2008), it is possible that firms face different tradeoffs when it comes to coordination costs versus benefits of breadth and flexibility associated with having dissimilar directors on a board. Coordination problems among board members with different opinions and objectives could cause firms that are already struggling to further delay restructuring and drain cash reserves. Panel D tests this possibility by conditioning the relation with value on the firm's cash flow. Empirically, the coefficients on the interaction between dispersion within a board and cash flow are positive and marginally significant. Thus, the presence of dissimilar directors on a board hurts less profitable firms more, consistent with such companies suffering more from director coordination costs. Shareholders of firms experiencing cash flow shortfalls value coordinated board monitoring and advisory efforts that can facilitate a turnaround and changes to business strategy, such as abandonment of negative-NPV projects.

In untabulated tests, the effect is not explained by differences in average director expertise or incentives, inclusion of four-digit SIC industry effects, or inclusion of state effects.

In summary, based on the various sensitivity tests the results are robust to alternative variable definitions, inclusion of additional controls, and the use of subsamples. We have shown that dispersion in director characteristics within boards has adverse value implications.

\section{Company financial choices}

In Table 6 we examine the impact of dispersion in director characteristics within a board on key value-relevant corporate choices: CEO pay and company financial decisions, such as investment spending, cash holding levels, leverage ratios, and dividend payout.

[Table 6] 
In Panel A, the level of CEO cash and total compensation is significantly higher and the proportion of incentive pay to the CEO is marginally lower in companies whose boards have dissimilar directors. The results are economically significant. All else given, a one standard deviation increase in the index of director dispersion increases the levels of cash pay and total pay by $10 \%$ and $12 \%$ of a standard deviation and decreases the proportion of incentive pay by $4 \%$ of a standard deviation, respectively. Setting CEO compensation requires coordinated action on the part of board members, and boards with dissimilar directors have more difficulty agreeing on CEO incentives and managerial pay curbs.

In Panel $\mathrm{B}$, the presence of dissimilar directors on the board is negatively related to investment spending, consistent with possible underinvestment when directors cannot agree and coordinate effectively on investment decisions. Next, we look at whether such firms conserve, pay out or divert the cash they did not invest and find that they hold less cash but maintain higher debt and dividend levels. The evidence suggests that boards with dissimilar directors struggle to coordinate on investment decisions and choose to commit to payouts to external claimholders. Existing work has shown that debt and dividends can serve as observable pre-commitments for poorly governed firms with significant agency conflicts (see, e.g., John et al. (2011)).

The effects are economically important. For example, all else equal, a one standard deviation increase in dispersion in director characteristics is associated with an increase in leverage equal to roughly $13 \%$ of the sample standard deviation of the ratio of debt to assets, an increase in dividends equal to $4 \%$ of the sample standard deviation of the dividend level, and decreases in cash and investment spending equal to $5 \%$ of the sample standard deviation of cash and investment, respectively. 
Our main tests and various robustness checks included a number of controls to mitigate omitted variable bias and endogeneity concerns. In an unreported test, lagging right-hand-side variables preserves the main results. In section 3.3 we analyze the reasons for the presence of dissimilar directors on boards and perform two-stage estimation. In section 3.4 we use an event study design to circumvent causality concerns.

\subsection{Accounting for the determinants of dispersion in director characteristics}

To empirically identify the effect of the presence of dissimilar directors on firm value, we isolate several external constraints on board composition that we believe to be relevant and exogenous determinants of dispersion in director characteristics within a board.

\section{External determinants}

First, firms may face regional constraints on director recruitment. Knyazeva et al. (2011) examine constraints on the availability of qualified prospective directors in the firm's region. They argue that the higher transportation and opportunity costs of nonlocal directors lead to geographic segmentation of director labor markets. Thus, if local supply of prospective directors in the firm's vicinity is limited, firms may be forced to select boards with more diversity in expertise and backgrounds than they would have done in the absence of director labor market frictions. As Knyazeva et al. (2011), Pirinsky and Wang (2006) and Chan et al. (1995) document the scarcity of firm relocations, we can treat corporate locations as predetermined for the overwhelming majority of our firms. Therefore, we use local availability of prospective directors to capture location-related determinants of the presence of dissimilar directors on boards. Following Knyazeva et al. (2011), we proxy the size of the local pool of prospective directors with executive expertise with the log of one plus the number of firms of similar or larger size located within a sixty-mile radius of the firm's headquarters. 
Second, regulatory factors may influence board composition. More stringent board and committee independence rules imposed by the Sarbanes-Oxley Act and governance requirements of major exchanges have increased demand for independent directors. Compliance with independence requirements can lead firms to appoint more heterogeneous boards if the overall supply of qualified independent directors with a given type of expertise is limited. Further, Hermalin (2005) argues that recent regulation has encouraged increased board diligence. The resulting greater emphasis on collection and interpretation of information about CEOs by the board could reinforce demand for more heterogeneity in director knowledge. We include a postSOX indicator to capture the effects of more stringent board and committee independence requirements of Sarbanes-Oxley and related governance reforms on board heterogeneity.

Third, the presence of boards comprised of dissimilar directors at other industry firms proxies the external component of coordination costs versus demand for flexibility and breadth of expertise arising from the nature of the projects in this industry. Further, as John and Kadyrzhanova (2008) show, governance of industry peers affects an individual firm's choice of governance practices. Failure to follow industry governance practices can make it harder for the firm to recruit directors. We use the median of dispersion in director characteristics within a board for the firm's Fama-French industry to capture industry practices.

\section{$\underline{\text { Controls }}$}

Besides these external constraints that we will use as instruments, we control for miscellaneous firm-level determinants of the presence of dissimilar directors on boards. First, complexity of the firm's operations increases the manager's reliance on board advice and the need for a complex board to provide effective monitoring (Adams and Ferreira (2008), Adams and Mehran (2003), Coles et al. (2008), Fama and Jensen (1983), Boone et al. (2007)). 
Therefore, we expect such firms to hire directors with varying skill sets to provide the breadth of expertise required for advising and overseeing top management and to have more variation in incentives to accommodate directors that play various roles on the board. We use firm size (log of firm market value) as the main proxy for complexity. In unreported tests, adding business segments and a foreign segment indicator, which are both correlated with firm size, does not significantly change the results.

Second, conditions of the business environment can increase the importance of swift and coordinated execution of the board's functions. Companies operating in uncertain environments or experiencing negative shocks stand to benefit more from increased efficiency of decision making, greater focus on core business strengths, and improved coordination among directors (Raheja (2005), Boone et al. (2007), Ferreira and Laux (2007), Denis and Sarin (1999), Easterwood et al. (2012)). We expect firms with low cash flows to have more similarity in director characteristics within the board. ${ }^{8}$ In unreported tests, we use an indicator for overall industry cash flow decline and find similar results.

Third, a company's growth prospects may affect the tasks performed by the board. Companies with valuable growth opportunities need boards to coordinate and evaluate projects in a timely and efficient manner. In addition, Raheja (2005) and Linck et al. (2008) point out that outside directors of growth firms face higher information costs, which could exacerbate coordination problems involving directors with dissimilar skill sets and interfere with the board's information production and advisory roles at growth firms. Young, growth firms could appoint directors sharing similar characteristics to minimize coordination costs. We use several measures

\footnotetext{
${ }^{8}$ Alternatively, the agency argument in Jensen (1986) would imply that high free cash flow firms require a higher level of board monitoring and more coordination among directors, resulting in the choice of more focused, homogeneous boards.
} 
of growth opportunities to avoid capturing a spurious relation with firm value: sales growth (annual change in net sales divided by lagged net sales), high tech sector indicator, and log of firm age. The average sample firm has been publicly listed for 26 years, and has demonstrated $0.10(10 \%)$ annual growth in sales, while $22 \%$ of the sample is in the high-tech sector. ${ }^{9}$

Fourth, managers have been shown to influence corporate boards. Boards might be less likely to scrutinize or dismiss CEOs with long tenure with the firm (see, e.g., Hermalin and Weisbach, 1998; Hermalin, 2005; Shivdasani and Yermack, 1999; Palia, 2001). CEOs with long tenure could have more influence over board appointments (Coles et al., 2008; Ryan and Wiggins, 2004; Adams et al. (2010)). More influential CEOs could appoint more like-minded directors, resulting in less board diversity. The dominant effect will be assessed empirically.

\section{$\underline{\text { First-stage results }}$}

We present empirical findings on the determinants of board dispersion in Table 7. Among external factors affecting board diversity, the level of board diversity in the firm's industry is positively related to the board diversity at a given firm. Firms constrained by a limited local pool of prospective directors have more dispersion in director characteristics within a board. Limited local availability of qualified prospective directors, coupled with the costs of hiring nonlocal directors, constrains firms in the hiring of outside directors and results in the appointment of a more diverse group of experts. Additionally, firms have been hiring increasingly dissimilar director experts in the period following Sarbanes Oxley Act (SOX). Companies having to comply with independence requirements, yet facing limitations on the aggregate supply of qualified directors, recruited directors with a variety of skill sets. The level of within-firm variation in director characteristics responds to the practices of industry peers.

\footnotetext{
${ }^{9}$ The following industries are classified as high tech, following Baginski et al. (2004): pharmaceuticals (2833-2836), computers (3570-3577), electronics (3600-3674), software (7371-7379), and R\&D services (8731-8734).
} 
[Table 7]

Some controls enter significantly. Large firms, which tend to be more complex, place more emphasis on the breadth of director expertise and allow for more variation in director ownership incentives. All else equal, a one standard deviation increase in firm size is associated with an increase in the variation in director industry expertise by around $71 \%$ percent of a standard deviation. ${ }^{10}$ Growth opportunities and the firm's lifecycle have a significant relation with variation in director characteristics, consistent with companies adjusting board composition as their growth options evolve. Mature companies have more variation in directors on their boards. All else equal, a one standard deviation decrease in sales growth is associated with an increase in within-board variation in industry expertise by about $17 \%$ of a standard deviation. A one standard deviation increase in firm age is associated with an increase in variation in industry expertise by $13 \%$ of a standard deviation. CEO tenure is negatively related to the presence of dissimilar directors. ${ }^{11}$ Ceteris paribus, a one-sigma decrease in managerial tenure is associated with a $16 \%$ sigma increase in within-board variation in industry expertise.

\section{$\underline{\text { Second-stage analysis: effects of dissimilar directors on valuation }}$}

In Table 8, we use the first-stage specification is based on Table 7 to reexamine the relation between firm value and predicted presence of dissimilar directors on the board in a two stage least square (2SLS) framework.

\section{[Table 8]}

The coefficients of interest retain their signs and significance in second-stage regressions. Most of the results (with the exception of variation in the number of board seats) remain both

\footnotetext{
${ }^{10}$ When discussing economic magnitudes of the coefficients, we refer to diversity in industry expertise for illustrative purposes. Economic effects for other diversity metrics are presented at the bottom of Table 7 .

${ }^{11}$ The observed negative association could be consistent with CEOs influencing the board to hire more like-minded directors or with other explanations, such as CEOs with greater bargaining power requiring oversight by more focused boards, so the tenure coefficient is more indicative of an association than a causal relationship.
} 
statistically significant and economically important after adjusting for endogeneity. Some estimates increase in magnitude. All else equal, a one standard deviation increase in the index of director dispersion has the effect of decreasing firm value by $33 \%$ of the sample standard deviation of market-to-book. Overall, two-stage results corroborate our main findings.

\subsection{Event study evidence}

Market reaction to acquisition announcements made by diverse boards

In this section we use market reaction to firm acquisition announcements to evaluate the shareholder wealth effects of having dissimilar directors on a board. Corporate acquisitions constitute major investment decisions that have significant implications for shareholder value. Acquisition decisions require management to gather information about the target firm's quality and potential synergies from the deal and often involve significant agency conflicts (most notably, empire building). If boards with dissimilar directors are less effective at monitoring and advising top management due to coordination problems, the average quality of acquisition decisions made by such firms should be worse, causing rational investors to react negatively to the announcement. The event study format helps us assess the value implications of board composition in a setting that is relatively immune to endogeneity concerns and interpretation issues sometimes raised in the context of market-to-book ratio tests.

Similar to Masulis et al. (2006) and other work, we examine the five-day $(-2$ to +2$)$ cumulative abnormal return (CAR) of the acquiring company around the announcement date. The results are qualitatively similar when the three-day $(-1$ to +1$)$ event window is used ${ }^{12}$. We rely on prior acquisition event studies for additional controls and determinants of acquirer

\footnotetext{
${ }^{12}$ The M\&A event study sample uses SDC Platinum data on bids by US acquirers with assets of at least $20 \mathrm{mln}$, seeking at least a 10 percent stake in a US target, with deal values of at least $1 \mathrm{mln}$ and at least 1 percent of acquirer market value of equity, and nonmissing data on controls and announcement returns. Returns are obtained from CRSP daily data. CARs are obtained from a single-factor market model.
} 
returns. We also control for the average levels of expertise in all tests to avoid finding a spurious effect. The tests are presented in Table 9 .

[Table 9]

Consistent with the prediction that boards with dissimilar directors have higher coordination costs, managers overseen by such boards tend to make worse acquisition decisions, all else equal. Within-board variation in director reputational incentives captured via other board seats has a similar negative effect on CARs. Variation in director ownership does not enter significantly.

The evidence obtained via an entirely different experimental design is generally in line with the results of firm value regressions. Based on the market reaction to corporate acquisition announcements, investors recognize the coordination problems stemming from differences in director expertise and reputational incentives within a board. These results support our earlier findings that the presence of dissimilar directors on the board hurts shareholder value. Market behavior around changes in the presence of dissimilar directors on a board

In addition to considering the overall relation between firm value and dissimilar directors and the effect of director dispersion on firm decisions (and market reaction to such decisions), we can assess the effect of having dissimilar directors on firm value by studying shareholder reaction to director replacement announcements. Rosenstein and Wyatt (1997) study the market reaction to the addition of insiders to the board. We adopt a similar event study approach to assess the shareholder wealth effects of board diversity changes.

We construct a sample of announcements involving director appointments to the board, departures of existing directors from the board, and director deaths from BoardEx. We calculate announcement returns around changes to the dispersion in director expertise or qualifications. 
We exclude announcements that only involve inside directors or that do not affect the level of similarity in director characteristics (or only have a trivial effect). We use the same sample selection criteria as in our main RiskMetrics sample (the sample and variables are described in more detail in Panel D of Table 1). Regression evidence is presented in Table 10. In addition to the change in dispersion and its interactions with key firm characteristics, we also control for changes in other board characteristics, including the proportion of outsiders on the board, board size, board qualifications, and executive expertise.

[Table 10]

Although the direct effect of the change in the presence of dissimilar directors is not significant, we find a negative interaction effect of the increase in dispersion and the firm's growth opportunities on the market reaction to the announcement. The result is consistent with the intuition that coordination problems associated with diverse boards are more pronounced for growth firms that require focus from their directors. By comparison, mature firms with assets in place appear to derive more benefit from the breadth of expertise delivered by boards with dissimilar directors as they advise the CEO on a wide range of potential projects that can expand the firm's limited investment opportunity set. The interaction of changes in director dispersion and firm size is not significant, rejecting the notion that dissimilar directors benefit complex firms' valuation.

We conclude that shareholder wealth effects of unanticipated changes to the presence of dissimilar directors on the board depend on the firm's growth needs and reflect the crucial costbenefit tradeoff of focus and coordination problems.

\section{Conclusion}


This paper has examined dispersion in director characteristics within corporate boards. On the one hand, having dissimilar directors within a board increases the board's overall breadth of expertise and flexibility. On the other hand, greater variation in director expertise and incentives within a board increases coordination costs, making it difficult for directors as a group to effectively advise and oversee top management.

Empirically, the presence of directors with dissimilar characteristics has a statistically and economically significant negative association with firm value and corporate outcomes that cannot be explained by previously documented differences in board independence, size, and expertise levels. Greater within-board dispersion in director expertise, and to some extent, reputational and ownership incentives, is associated with lower firm value. This finding emphasizes the benefits of a focused board and the adverse effects of coordination problems among board members on the board's collective ability to advise and oversee management. Dissimilarities among board members are also associated with a lower share of incentive pay in managerial pay, lower cash holdings in the firm, and lower investment spending. To compensate for less effective board monitoring, such firms pre-commit to higher debt and dividend levels.

We use several approaches to account for the possibility of reverse causality or simultaneity. First, we incorporate a number of determinants of firm value, as well as additional board, industry, and state controls, in our tests. Second, we identify potential exogenous constraints and market frictions arising from the firm's environment that can affect board composition: constraints on the local supply of qualified directors, regulatory shifts, and industry board governance practices, which prompt firms to hire more/fewer dissimilar directors relative to their monitoring and advisory needs. After accounting for endogeneity in a two-stage setting, dispersion in director characteristics continues to have a negative effect on valuation. Third, we 
perform an event study to assess whether managers overseen by boards with dissimilar directors engage in more value destruction in the course of acquisitions. Consistent with our other findings, acquisitions by firms whose boards are comprised of dissimilar directors are worse for shareholder wealth. Finally, we study the market reaction to changes in the dispersion of director characteristics within a board and find that the market responds less favorably to the addition of dissimilar directors to the boards of growth firms, which gain less from breadth in director skill sets and suffer more from coordination problems.

Overall, within-board variation in director characteristics, particularly, experience and incentives is a significant factor in the board's operation. Increased coordination costs associated with the presence of dissimilar directors on the board reduce the effectiveness of board decision making and oversight and advisory functions. 


\section{References}

Adams, Renee, and Daniel Ferreira, 2007, A theory of friendly boards, Journal of Finance 62(1), 217-250.

Adams, Renee, and Daniel Ferreira, 2008, Do directors perform for pay? Journal of Accounting and Economics 46(1), 154-171.

Adams, Renee, and Daniel Ferreira, 2009, Women in the boardroom and their impact on governance and performance, Journal of Financial Economics 94(2), 291-309.

Adams, Renee, Benjamin E. Hermalin, and Michael Weisbach, 2010, The role of board of directors in corporate governance: A conceptual framework survey, Journal of Economic Literature 48, 58-107.

Adams, Renee, and Hamid Mehran, 2003, Board structure and banking firm performance, Federal Reserve Bank of New York Economic Policy Review 9, 123-142.

Agrawal, Anup, and Charles R. Knoeber, 1996, Firm performance and mechanisms to control agency problems between managers and shareholders, Journal of Financial and Quantitative Analysis 31(3), 377-397.

Ahern, Kenneth, and Amy Dittmar, 2012, The changing of the boards: the impact on firm valuation of mandated female board representation, Quarterly Journal of Economics 127(1), 137-197.

Alesina, Alberto, Enrico Spolaore, and Romain Wacziarg, 2000, Economic integration and political disintegration, American Economic Review 90(5), 1276-1296.

Anderson, Ronald, David Reeb, Arun Upadhyay, and Wanli Zhao, 2011, The economics of director heterogeneity, Financial Management 40(1), 5-38.

Baginski, Stephen P., John M. Hassell, and Michael D. Kimbrough, 2004, Why do managers explain their earnings forecasts? Journal of Accounting Research 42(1), 1-29.

Baranchuk, Nina, and Phil Dybvig, 2009, Consensus in diverse corporate boards, Review of Financial Studies 22(2), 715-747.

Bardhan, Pranab, 1993, Symposium on management of local commons, Journal of Economics Perspectives 7(4), 87-92.

Bergstrom, Theodore, Lawrence Blume, and Hal Varian, 1986, On the private provision of public goods, Journal of Public Economics 29(1), 25-49.

Bhagat, Sanjai, and Bernard Black, 2002, The non-correlation between board independence and long-term firm performance, Journal of Corporation Law 27, 231-273

Boone, Audra, Laura Field, Jonathan Karpoff, and Charu Raheja, 2007, The determinants of corporate board size and composition: An empirical analysis. Journal of Financial Economics 85(1), 66-101.

Carter, David A., Betty J. Simkins, and W. Gary Simpson, 2003, Corporate governance, board diversity, and firm value, Financial Review 38 (1), 33-53.

Chan, Su Han, George W. Gau, and Ko Wang, 1995, Stock market reaction to capital investment decisions: evidence from business relocations, Journal of Financial and Quantitative Analysis 30(1), 81-100.

Coles, Jeffrey, Naveen Daniel, and Lalitha Naveen, 2008, Boards: Does one size fit all? Journal of Financial Economics 87(2), 329-356. 
Cornes, Richard, 1993, Dyke maintenance and other stories: some neglected types of public goods, Quarterly Journal of Economics 108(1), 259-271.

Denis, David J., and Atulya Sarin, 1999, Ownership and board structures in publicly traded corporations, Journal of Financial Economics 52(2), 187-223.

Easterwood, John, Ozgur Ince and Charu Raheja, 2012, The evolution of boards and CEOs following a performance decline, forthcoming, Journal of Corporate Finance.

Fama, Eugene, and Michael C. Jensen, 1983, Separation of ownership and control, Journal of Law and Economics 26(2), 301-325.

Ferreira, Miguel, and Paul Laux, 2007, Corporate governance, idiosyncratic risk, and information flow, Journal of Finance 62, 951-988.

Fich, Eliezer, and Anil Shivdasani, 2006, Are busy boards effective monitors? Journal of Finance 61(2), 689-724.

Fich, Eliezer, and Anil Shivdasani, 2007, Financial fraud, director reputation, and shareholder wealth, Journal of Financial Economics 86, 306-336.

Fluck, Zsuzsanna, and Naveen Khanna, 2011, Support, oppose or rubberstamp? A theory of collective decision making of corporate boards? Working paper.

Hamilton, Barton H., Jack A. Nickerson, and Hideo Owan, 2003, Team incentives and worker heterogeneity: An empirical analysis of the impact of teams on productivity and participation, Journal of Political Economy 111(3), 465-497.

Harris, Milton, and Artur Raviv, 2008, A theory of board control and size, Review of Financial Studies 21(4), 1797-1832.

Hermalin, Benjamin, 2005, Trends in corporate governance, Journal of Finance 60(5), 23512384.

Hermalin, Benjamin, and Michael Weisbach, 1998, Endogenously chosen boards of directors and their monitoring of the CEO, American Economic Review 88(1), 96-118.

Jensen, Michael C., 1986, Agency costs of free cash flow, corporate finance, and takeovers, American Economic Review 76(2), 323-329.

Jensen, Michael C., 1993, The modern industrial revolution, exit, and the failure of internal control systems, Journal of Finance 48(3), 831-880.

John, Kose, Anzhela Knyazeva, and Diana Knyazeva, 2011, Governance and precommitment: Antitakeover laws, structure of payouts, and the dividend-debt tradeoff, Working paper.

John, Kose, and Dalida Kadyrzhanova, 2008, Peer effects in corporate governance, Working paper.

Kandel, Eugene, and Edward Lazear, 1992, Peer pressure and partnerships, Journal of Political Economy 100(4), 801-817.

Klein, April, 1998, Firm performance and board committee structure, Journal of Law and Economics 41(1), 275-304.

Knyazeva, Anzhela, Diana Knyazeva, and Ronald W. Masulis, 2011, Local director talent and board composition, Working paper.

Ledyard, John, 1995, Public goods: A survey of experimental research, In: Handbook of Experimental Economics, eds. Kagel, John and Alvin Roth. Princeton University Press, Princeton, 111-194. 
Linck, James S., Jeffry M. Netter, and Tina Yang, 2008, The determinants of board structure, Journal of Financial Economics 87(2), 308-328.

Masulis, Ronald W., and Shawn Mobbs, 2011, Are all inside directors the same? CEO entrenchment or board enhancement, Journal of Finance 66(3), 823-872.

Masulis, Ronald W., Cong Wang, and Fei Xie, 2006, Corporate governance and acquirer returns, Journal of Finance 62(4), 1851-1889.

Mehran, Hamid, 1995, Executive compensation structure, ownership, and firm performance. Journal of Financial Economics 38(2), 163-184.

Page, Scott, 2007, The difference: how the power of diversity creates better groups, firms, schools and societies. Princeton, NJ: Princeton University Press

Palia, Darius, 2001, The endogeneity of managerial compensation in firm value: a solution, Review of Financial Studies 14(3), 735-764.

Pirinsky, Christo, and Qinghai Wang, 2006, Does corporate headquarters location matter for stock returns? Journal of Finance 61(4), 1991-2015.

Raheja, Charu, 2005, Determinants of board size and composition: a theory of corporate boards, Journal of Financial and Quantitative Analysis 40(2), 283-306.

Rosenstein, Stuart, and Jeffrey G. Wyatt, 1997, Inside directors, board effectiveness and shareholder wealth, Journal of Financial Economics 44(2), 229-250.

Ryan, Harley, and Roy Wiggins III, 2004, Who is in whose pocket? Director compensation, board independence, and barriers to effective monitoring, Journal of Financial Economics 73(3), 497-524.

Shivdasani, Anil, and David Yermack, 1999, CEO involvement in the selection of new board members: An empirical analysis, Journal of Finance 54(5), 1829-1853.

Sibert, Anne, 2003, Monetary policy committees: individual and collective reputations, Review of Economic Studies 70(3), 649-665.

Steiner, Ivan D., 1966, Models for inferring relationships between group size and potential group productivity, Behavioral Science 11(4), 273-283.

Vigdor, Jacob, 2004, Community composition and collective action: analyzing initial mail response to the 2000 Census, Review of Economics and Statistics 86(1), 303-312.

Yermack, David, 1996, High market valuation of companies with a small board of directors, Journal of Financial Economics 40(2), 185-211.

Yermack, David, 2004, Remuneration, retention, and reputation incentives for outside directors, Journal of Finance, 59(5), 2281-2308. 


\section{Table 1 . Summary statistics}

The sample and other variables are described in Appendix B.

\begin{tabular}{|c|c|c|c|c|c|}
\hline Dispersion $^{a}$ & Obs & Mean & Med & $\mathrm{SD}$ & Description \\
\hline [industry expertise] & 4130 & 0.71 & 0.78 & 0.22 & $\begin{array}{l}\text { Defined as } 1-\sum x_{k}^{2} \text {, where } x_{k} \text { is the proportion of other seats } \\
\text { held by the firm's directors in Fama-French industry } k \text {; } \\
\text { defined if board members as a group hold seats at two or } \\
\text { more other firms with nonmissing Board Analyst and } \\
\text { Compustat data., Dispersion (key) is defined similarly, } \\
\text { except it uses the most influential appointment for directors } \\
\text { with multiple seats at other firms (insider; lead director; long } \\
\text { tenure; large firm size). }\end{array}$ \\
\hline [size expertise] & 4091 & 0.55 & 0.62 & 0.21 & $\begin{array}{l}\text { Defined as } 1-\sum x_{k}^{2} \text {, where } x_{k} \text { is the proportion of other seats } \\
\text { held by the firm's directors at firms in size quartile } k^{\text {a,b }}\end{array}$ \\
\hline [risk expertise] & 4087 & 0.56 & 0.64 & 0.22 & Defined similarly, except it uses firm risk quartiles. ${ }^{a, b}$ \\
\hline [lifecycle expertise] & 4092 & 0.56 & 0.63 & 0.21 & Defined similarly, except it uses firm age quartiles $k .^{\mathrm{a}, \mathrm{b}}$ \\
\hline [board seats] & 4130 & 0.67 & 0.69 & 0.10 & $\begin{array}{l}\text { Defined as } 1-\Sigma d_{j}^{2} \text {, where } d_{j} \text { is the share of directors with } j \\
(1 \ldots 5,>5) \text { board seats among the firm's directors. }{ }^{\text {a,c }}\end{array}$ \\
\hline [ownership] & 4130 & 0.54 & 0.61 & 0.27 & $\begin{array}{l}\text { Defined as } 1-\Sigma s_{i}{ }^{2} \text {, where } s_{i} \text { is director } i \text { 's share in total shares } \\
\text { held by the firm's directors (if positive). }\end{array}$ \\
\hline [tenure] & 4130 & 0.70 & 0.75 & 0.16 & $\begin{array}{l}\text { Defined as } 1-\Sigma t_{k}^{2} \text {, where } t_{k} \text { is the proportion of directors with } \\
k(0 \ldots 35,>35) \text { years of tenure on the firm's board. }{ }^{\text {a,c }}\end{array}$ \\
\hline index [expertise] & 4086 & 0.59 & 0.65 & 0.18 & $\begin{array}{l}\text { Average of dispersion in industry expertise, size expertise, } \\
\text { risk expertise, and lifecycle expertise. }\end{array}$ \\
\hline $\begin{array}{l}\text { index [expertise \& } \\
\text { incentives] }\end{array}$ & 4130 & 0.64 & 0.66 & 0.14 & $\begin{array}{l}\text { Average of dispersion in industry expertise, board seats, and } \\
\text { ownership incentives. Dispersion index (2) averages } \\
\text { dispersion in industry expertise, size expertise, lifecycle } \\
\text { expertise, risk expertise, board seats, and ownership. }\end{array}$ \\
\hline
\end{tabular}

${ }^{a}$ Board Analyst, unless specified otherwise. Higher values reflect more dispersion.

${ }^{\mathrm{b}}$ All board members used unless specified otherwise in subsequent tables.

${ }^{\mathrm{c}}$ Independent directors used. 
Table 2. Univariate evidence: board dispersion and firm value

This table presents two-sided t-tests of means of firm value by subsamples based on board dispersion measures. Sample and variable definitions are shown in Table 1 and the Appendix. For each dispersion measure in the first column, we report mean market-to-book (M/B) within subsamples of board dispersion, difference in $\mathrm{M} / \mathrm{B}$ between subsamples, and differences in mean $\mathrm{M} / \mathrm{B}$ between subsamples as a percentage of the standard deviation of $\mathrm{M} / \mathrm{B}$ in the full sample. Significance at $1 \%, 5 \%$, and $10 \%$ is denoted with ${ }^{* * *}$, ${ }^{* *}$, and ${ }^{*}$.

\begin{tabular}{|c|c|c|c|c|c|c|c|c|c|c|}
\hline \multirow[b]{2}{*}{ Dispersion } & \multicolumn{2}{|c|}{$\begin{array}{l}\text { Mean M/B in } \\
\text { the subsample }\end{array}$} & \multicolumn{3}{|c|}{$\begin{array}{c}\Delta \mathrm{M} / \mathrm{B} \\
\text { (top-bottom) }\end{array}$} & \multicolumn{2}{|c|}{$\begin{array}{l}\text { Mean } M / B \text { in } \\
\text { the subsample }\end{array}$} & \multicolumn{3}{|c|}{$\begin{array}{c}\Delta \mathrm{M} / \mathrm{B} \\
\text { (top-bottom) }\end{array}$} \\
\hline & $\begin{array}{c}\text { bottom } \\
50 \%\end{array}$ & $\begin{array}{l}\text { top } \\
50 \% \\
\end{array}$ & $\Delta$ & $\frac{\Delta}{\sigma(\mathrm{M} / \mathrm{B})}$ & Sig. & $\begin{array}{c}\text { bottom } \\
25 \%\end{array}$ & $\begin{array}{c}\text { top } \\
75 \%\end{array}$ & $\Delta$ & $\frac{\Delta}{\sigma(\mathrm{M} / \mathrm{B})}$ & Sig. \\
\hline [industry expertise] & 1.57 & 1.16 & -0.41 & $-24.8 \%$ & *** & 1.59 & 1.06 & -0.53 & $-32.2 \%$ & $* * *$ \\
\hline [board seats] & 1.50 & 1.26 & -0.24 & $-14.4 \%$ & $* * *$ & 1.59 & 1.22 & -0.37 & $-22.4 \%$ & $* * *$ \\
\hline [ownership] & 1.46 & 1.30 & -0.16 & $-9.5 \%$ & ${ }^{* * *}$ & 1.54 & 1.22 & -0.32 & $-19.1 \%$ & ${ }^{* * *}$ \\
\hline [size expertise] & 1.46 & 1.29 & -0.18 & $-10.6 \%$ & $* * *$ & 1.38 & 1.26 & -0.11 & $-6.7 \%$ & $*$ \\
\hline [risk expertise] & 1.49 & 1.26 & -0.23 & $-13.7 \%$ & $* * *$ & 1.49 & 1.23 & -0.26 & $-15.7 \%$ & $* * *$ \\
\hline [lifecycle expertise] & 1.51 & 1.23 & -0.28 & $-16.9 \%$ & $* * *$ & 1.51 & 1.18 & -0.33 & $-20.0 \%$ & $* * *$ \\
\hline index [expertise] & 1.54 & 1.22 & -0.32 & $-19.5 \%$ & ${ }^{* * *}$ & 1.61 & 1.14 & -0.47 & $-28.4 \%$ & ${ }^{* * *}$ \\
\hline index [expertise \& incentives] & 1.52 & 1.24 & -0.27 & $-16.6 \%$ & ${ }^{* * *}$ & 1.60 & 1.12 & -0.48 & $-29.2 \%$ & ${ }^{* * *}$ \\
\hline
\end{tabular}


Table 3. Multivariate evidence: board dispersion and firm value

Sample and variable definitions are shown in Table 1 and the Appendix. Regressions of market-to-book on board dispersion, controls, three-digit SIC industry effects, and year effects. Panel A uses the main measures of board dispersion. Panel B uses additional measures of board dispersion. The economic magnitude of the effect is defined as the change in market-to-book, expressed as a percentage of standard deviation of market-to-book, in response to a one standard deviation change in the explanatory variable, all else equal. Robust $t$-statistics clustered by firm are italicized. Significance at $1 \%, 5 \%$, and $10 \%$ is denoted with ${ }^{* * *},{ }^{* *}$, and $^{*}$.

Panel A: Main results

\begin{tabular}{|c|c|c|c|c|c|c|}
\hline \multirow[b]{2}{*}{ Dispersion [industry expertise] } & \multicolumn{2}{|l|}{ I } & \multicolumn{2}{|l|}{ II } & \multicolumn{2}{|l|}{ III } \\
\hline & $-1.582^{*}$ & & & & & \\
\hline & -6.74 & & & & & \\
\hline \multirow[t]{2}{*}{ Dispersion [board seats] } & & & -1.354 & *** & & \\
\hline & & & -4.91 & & & \\
\hline \multirow[t]{2}{*}{ Dispersion [ownership] } & & & & & -0.672 & $2^{* * *}$ \\
\hline & & & & & -3.58 & \\
\hline \multirow[t]{2}{*}{ Firm size } & $0.266^{*}$ & ** & 0.185 & *** & 0.177 & 7** \\
\hline & 3.87 & & 3.10 & & 2.91 & \\
\hline \multirow[t]{2}{*}{ Firm age } & $-0.285^{*}$ & ** & -0.292 & **** & -0.292 & $2^{* * *}$ \\
\hline & -4.70 & & -4.63 & & -4.74 & \\
\hline \multirow[t]{2}{*}{ Sales growth } & $0.324^{*}$ & * & 0.417 & *** & 0.374 & $t^{* *}$ \\
\hline & 2.00 & & 2.74 & & 2.48 & \\
\hline \multirow[t]{2}{*}{ Cash flow } & $1.578^{*}$ & *** & 1.494 & *** & 1.556 & $5^{* * *}$ \\
\hline & 3.60 & & 3.44 & & 3.61 & \\
\hline \multirow[t]{2}{*}{ Tangible assets } & -0.057 & & -0.162 & & -0.040 & \\
\hline & -0.18 & & -0.51 & & -0.12 & \\
\hline \multirow[t]{2}{*}{ CEO tenure } & 0.046 & & 0.066 & & 0.075 & $5^{*}$ \\
\hline & 1.18 & & 1.63 & & 1.86 & \\
\hline Obs. & 4130 & & 4130 & & 4130 & \\
\hline $\mathrm{R}^{2}$ & 0.22 & & 0.19 & & 0.20 & \\
\hline \multicolumn{7}{|l|}{ Economic magnitudes of the effects } \\
\hline Dispersion [industry expertise] & $-20.8 \%$ & ${ }^{* * *}$ & & & & \\
\hline Dispersion [board seats] & & & $-8.5 \%$ & *** & & \\
\hline Dispersion [ownership] & & & & & $-10.8 \% *$ & \\
\hline Firm size & $22.4 \%$ & $* * *$ & $15.6 \%$ & *** & $14.9 \%$ * & *** \\
\hline Firm age & $-14.8 \%$ & ${ }^{* * *}$ & $-15.2 \%$ & *** & $-15.2 \% *$ & *** \\
\hline Sales growth & $4.3 \%$ & ** & $5.6 \%$ & *** & $5.0 \%{ }^{*}$ & ** \\
\hline Cash flow & $11.0 \%$ & *** & $10.5 \%$ & *** & $10.9 \%$ * & *** \\
\hline Tangible assets & $-0.7 \%$ & & $-2.0 \%$ & & $-0.5 \%$ & \\
\hline CEO tenure & $2.3 \%$ & & $3.4 \%$ & & $3.8 \% *$ & * \\
\hline
\end{tabular}


Panel B: Additional measures of board dispersion

\begin{tabular}{|c|c|c|c|c|c|c|c|c|c|c|}
\hline Dep. var.: Firm value & I & & II & & III & & IV & & $\mathrm{V}$ & \\
\hline Dispersion [size expertise] & -0.609 & ${ }^{* * * *}$ & & & & & & & & \\
\hline & -4.18 & & & & & & & & & \\
\hline Dispersion [risk expertise] & & & -0.842 & *** & & & & & & \\
\hline & & & -4.96 & & & & & & & \\
\hline Dispersion [lifecycle expertise] & & & & & -0.827 & *** & & & & \\
\hline & & & & & -5.22 & & & & & \\
\hline Dispersion index [expertise] & & & & & & & -1.436 & & & \\
\hline & & & & & & & -6.19 & & & \\
\hline Dispersion index [expertise \& incentives] & & & & & & & & & -2.565 & *** \\
\hline & & & & & & & & & -5.87 & \\
\hline Firm size & 0.186 & $* * *$ & 0.213 & *** & 0.201 & *** & 0.234 & *** & 0.248 & *** \\
\hline & 3.02 & & 3.32 & & 3.21 & & 3.55 & & 3.62 & \\
\hline Firm age & -0.314 & ${ }^{* * *}$ & -0.303 & *** & -0.317 & *** & -0.306 & *** & -0.265 & *** \\
\hline & -4.90 & & -4.84 & & -4.97 & & -4.87 & & -4.45 & \\
\hline Sales growth & 0.394 & ${ }^{* *}$ & 0.383 & ${ }^{* *}$ & 0.387 & ** & 0.356 & ** & 0.311 & ${ }^{* *}$ \\
\hline & 2.53 & & 2.41 & & 2.51 & & 2.21 & & 1.99 & \\
\hline Cash flow & 1.539 & $* * *$ & 1.549 & $* * *$ & 1.505 & *** & 1.577 & *** & 1.555 & *** \\
\hline & 3.47 & & 3.37 & & 3.48 & & 3.45 & & 3.62 & \\
\hline Tangible assets & -0.095 & & -0.084 & & -0.073 & & -0.071 & & -0.020 & \\
\hline & -0.29 & & -0.26 & & -0.22 & & -0.22 & & -0.06 & \\
\hline CEO tenure & 0.070 & * & 0.054 & & 0.068 & * & 0.051 & & 0.051 & \\
\hline & 1.72 & & 1.33 & & 1.69 & & 1.28 & & 1.34 & \\
\hline Obs. & 4091 & & 4087 & & 4092 & & 4086 & & 4130 & \\
\hline $\mathrm{R}^{2}$ & 0.19 & & 0.20 & & 0.20 & & 0.21 & & 0.22 & \\
\hline Economic magnitudes of the effects & & & & & & & & & & \\
\hline Dispersion [size expertise] & $-7.8 \%$ & *** & & & & & & & & \\
\hline Dispersion [risk expertise] & & & $-11.3 \%$ & *** & & & & & & \\
\hline Dispersion [lifecycle expertise] & & & & & $-10.4 \%$ & ${ }^{* * *}$ & & & & \\
\hline Dispersion index [expertise] & & & & & & & $-15.5 \%$ & $* * *$ & & \\
\hline Dispersion index [expertise \& incentives] & & & & & & & & & $-21.4 \%$ & *** \\
\hline Firm size & $15.6 \%$ & $* * *$ & $17.9 \%$ & $* * *$ & $16.9 \%$ & $* * *$ & $19.7 \%$ & ${ }^{* * *}$ & $20.8 \%$ & ${ }^{* * *}$ \\
\hline Firm age & $-16.3 \%$ & *** & $-15.7 \%$ & *** & $-16.5 \%$ & $* * *$ & $-15.9 \%$ & ${ }^{* * *}$ & $-13.8 \%$ & *** \\
\hline Sales growth & $5.3 \%$ & ** & $5.1 \%$ & ** & $5.2 \%$ & ** & $4.8 \%$ & ** & $4.2 \%$ & $* *$ \\
\hline Cash flow & $10.8 \%$ & *** & $10.8 \%$ & *** & $10.5 \%$ & ${ }^{* * *}$ & $11.0 \%$ & $* * *$ & $10.9 \%$ & *** \\
\hline Tangible assets & $-1.2 \%$ & & $-1.0 \%$ & & $-0.9 \%$ & & $-0.9 \%$ & & $-0.3 \%$ & \\
\hline CEO tenure & $3.6 \%$ & $*$ & $2.8 \%$ & & $3.5 \%$ & $*$ & $2.6 \%$ & & $2.6 \%$ & \\
\hline
\end{tabular}


Table 4. Robustness tests: analysis within subsamples

Regressions of market-to-book on board dispersion, controls, three-digit SIC industry effects, and year effects. Panel A uses firms with board size below 10 . Panel B uses firms with the average number of seats held by directors below 3. Variables are defined in Table 1 and the Appendix. Robust t-statistics clustered by firm are italicized. Significance at $1 \%, 5 \%$, and $10 \%$ is denoted with ${ }^{* * *},{ }^{* *}$, and ${ }^{*}$.

\section{Panel A: Small boards subsample}

Dep. var.: Firm value

Dispersion [industry expertise]

$\begin{array}{ll}\text { I } & \text { II } \\ -1.276^{* * *} & \\ -5.56 & \\ & -0.613^{* * *} \\ & -3.18\end{array}$

Dispersion [risk expertise]

Dispersion [lifecycle expertise]

Dispersion index [expertise]

Dispersion [board seats]

Dispersion [ownership]

Dispersion index [expertise \& incentives]

III

IV

$-0.618^{* * *}$
-3.14

Firm size

Firm age

Sales growth

Cash flow

Tangible assets

\section{CEO tenure}

Obs.

Obs

$+2$

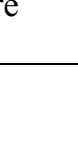

[expertise \& incentives]

III

V




Panel B: Boards with non-busy directors

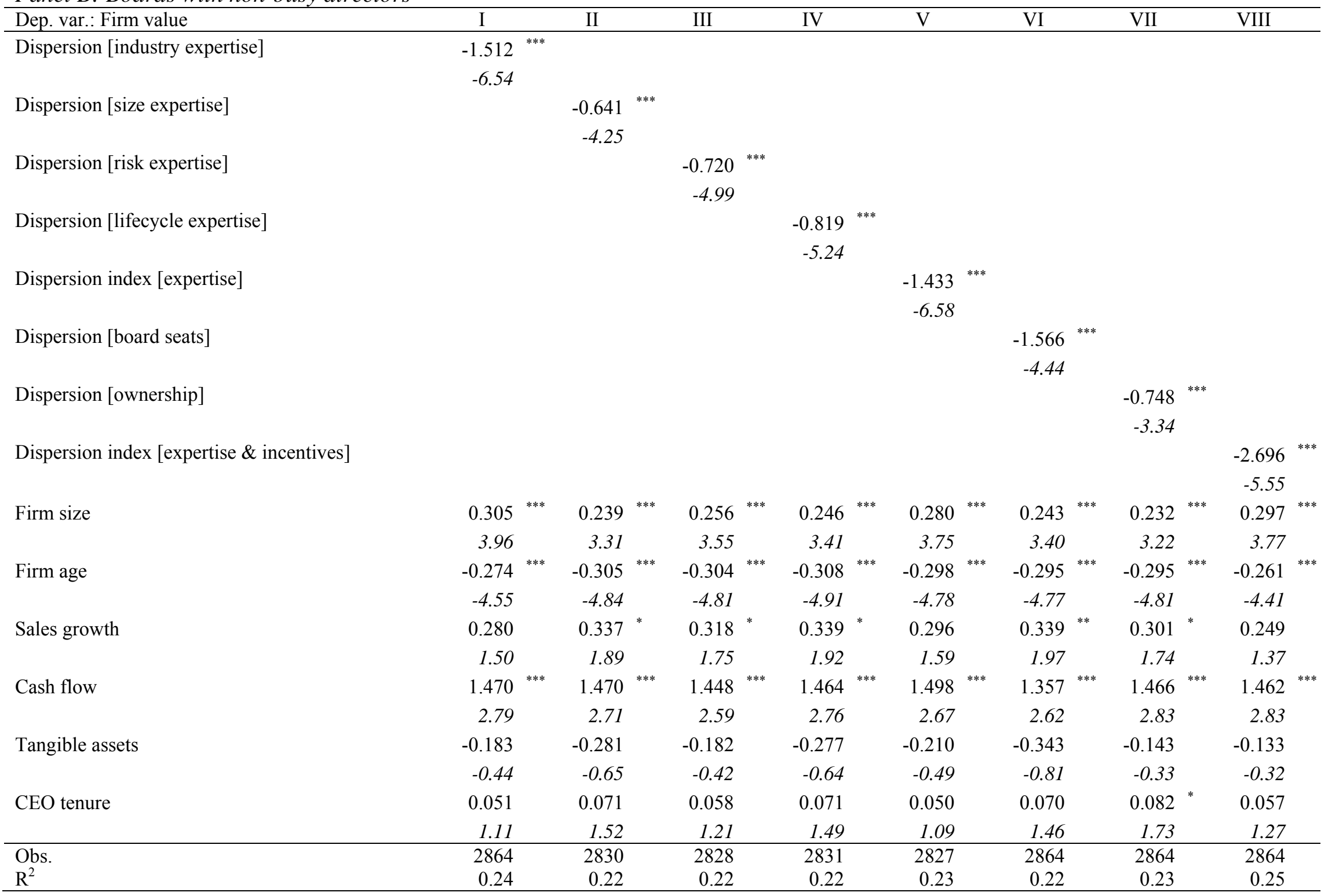




\section{Table 5. Robustness tests: additional controls}

Regressions of market-to-book on dispersion, controls, three-digit SIC industry effects, and year effects. Panel A adds board independence and size. Panel B adds other controls. Panel C uses other dispersion measures; columns II, IV-VI only use independent directors. Panel D interacts dispersion with cash flow. Variables are defined in Table 1 and the Appendix. Robust t-statistics clustered by firm are italicized. Significance at $1 \%, 5 \%$, and $10 \%$ is denoted with ${ }^{* * *}$, ${ }^{* *}$, and ${ }^{*}$.

\section{Panel A: Controlling for board independence and size}

\begin{tabular}{|c|c|c|c|c|c|c|c|c|c|c|c|c|c|c|c|c|}
\hline Dep. var.: Firm value & I & & II & & III & & IV & & $\mathrm{V}$ & & VI & & VII & & VIII & \\
\hline \multirow[t]{2}{*}{ Dispersion [industry expertise] } & -1.222 & $* * *$ & & & & & & & & & & & & & & \\
\hline & -5.76 & & & & & & & & & & & & & & & \\
\hline \multirow[t]{2}{*}{ Dispersion [size expertise] } & & & -0.347 & $* * *$ & & & & & & & & & & & & \\
\hline & & & -2.61 & & & & & & & & & & & & & \\
\hline \multirow[t]{2}{*}{ Dispersion [risk expertise] } & & & & & -0.616 & $* * *$ & & & & & & & & & & \\
\hline & & & & & -3.87 & & & & & & & & & & & \\
\hline \multirow[t]{2}{*}{ Dispersion [lifecycle expertise] } & & & & & & & -0.616 & & & & & & & & & \\
\hline & & & & & & & -3.94 & & & & & & & & & \\
\hline \multirow[t]{2}{*}{ Dispersion index [expertise] } & & & & & & & & & -1.086 & & & & & & & \\
\hline & & & & & & & & & -5.02 & & & & & & & \\
\hline \multirow[t]{2}{*}{ Dispersion [board seats] } & & & & & & & & & & & -0.506 & & & & & \\
\hline & & & & & & & & & & & -1.60 & & & & & \\
\hline \multirow[t]{2}{*}{ Dispersion [ownership] } & & & & & & & & & & & & & -0.568 & & & \\
\hline & & & & & & & & & & & & & -3.08 & & & \\
\hline \multirow[t]{2}{*}{ Dispersion index [expertise $\&$ incentives] } & & & & & & & & & & & & & & & -2.099 & ${ }^{* * *}$ \\
\hline & & & & & & & & & & & & & & & -4.78 & \\
\hline \multirow[t]{2}{*}{ Firm size } & 0.325 & $* * *$ & 0.278 & $* * *$ & 0.296 & $* * *$ & 0.288 & *** & 0.304 & $* * *$ & 0.274 & $* * *$ & 0.274 & $* * *$ & 0.309 & $* * *$ \\
\hline & 4.43 & & 4.01 & & 4.15 & & 4.11 & & 4.23 & & 4.01 & & 4.01 & & 4.25 & \\
\hline \multirow[t]{2}{*}{ Firm age } & -0.213 & $* * *$ & -0.217 & $* * *$ & -0.215 & $* * *$ & -0.225 & *** & -0.226 & $* * *$ & -0.205 & $* * *$ & -0.201 & $* * *$ & -0.203 & *** \\
\hline & -3.64 & & -3.64 & & -3.63 & & -3.80 & & -3.77 & & -3.50 & & -3.47 & & -3.51 & \\
\hline \multirow[t]{2}{*}{ Sales growth } & 0.303 & $*$ & 0.351 & $* *$ & 0.346 & $* *$ & 0.348 & ** & 0.332 & $* *$ & 0.359 & $* *$ & 0.327 & $* *$ & 0.296 & * \\
\hline & 1.88 & & 2.27 & & 2.18 & & 2.25 & & 2.07 & & 2.35 & & 2.16 & & 1.90 & \\
\hline \multirow[t]{2}{*}{ Cash flow } & 1.462 & $* * *$ & 1.408 & $* * *$ & 1.434 & $* * *$ & 1.384 & $* * *$ & 1.460 & $* * *$ & 1.400 & $* * *$ & 1.428 & $* * *$ & 1.444 & $* * *$ \\
\hline & & & & & 35 & & & & & & & & & & & \\
\hline
\end{tabular}




\begin{tabular}{|c|c|c|c|c|c|c|c|c|}
\hline & 3.32 & 3.17 & 3.12 & 3.17 & 3.18 & 3.21 & 3.29 & 3.33 \\
\hline \multirow[t]{2}{*}{ Tangible assets } & -0.018 & -0.025 & -0.019 & -0.006 & -0.012 & -0.073 & 0.009 & 0.014 \\
\hline & -0.06 & -0.08 & -0.06 & -0.02 & -0.04 & -0.23 & 0.03 & 0.05 \\
\hline \multirow[t]{2}{*}{ CEO tenure } & 0.009 & 0.020 & 0.009 & 0.019 & 0.010 & 0.020 & 0.023 & 0.013 \\
\hline & 0.23 & 0.53 & 0.24 & 0.49 & 0.26 & 0.53 & 0.59 & 0.36 \\
\hline \multirow[t]{2}{*}{ Board size } & $-1.237^{* * *}$ & $-1.482^{* * *}$ & $-1.430^{* * *}$ & $-1.440^{* * *}$ & $-1.326^{* * *}$ & $-1.479^{* * *}$ & $-1.474^{* * *}$ & $-1.183^{* * *}$ \\
\hline & -5.69 & -6.32 & -6.20 & -6.16 & -5.90 & -5.80 & -6.55 & -5.61 \\
\hline \multirow[t]{2}{*}{ Board independence } & 0.257 & 0.185 & 0.310 & 0.320 & $0.434^{*}$ & 0.033 & 0.201 & $0.474^{*}$ \\
\hline & 1.15 & 0.84 & 1.38 & 1.37 & 1.83 & 0.15 & 0.87 & 1.89 \\
\hline Obs. & 4130 & 4091 & 4087 & 4092 & 4086 & 4130 & 4130 & 4130 \\
\hline $\mathrm{R}^{2}$ & 0.24 & 0.23 & 0.23 & 0.23 & 0.23 & 0.22 & 0.23 & 0.24 \\
\hline
\end{tabular}


Panel B: Controlling for additional explanatory variables

\begin{tabular}{|c|c|c|c|c|c|c|c|c|c|c|c|c|c|c|c|c|}
\hline Dep. var.: Firm value & I & & II & & III & & IV & & $\mathrm{V}$ & & VI & & VII & & VIII & \\
\hline \multirow[t]{2}{*}{ Dispersion [industry expertise] } & -1.563 & $* * *$ & & & & & & & & & & & & & & \\
\hline & -6.52 & & & & & & & & & & & & & & & \\
\hline \multirow[t]{2}{*}{ Dispersion [size expertise] } & & & -0.524 & *** & & & & & & & & & & & & \\
\hline & & & -3.90 & & & & & & & & & & & & & \\
\hline \multirow[t]{2}{*}{ Dispersion [risk expertise] } & & & & & -0.729 & *** & & & & & & & & & & \\
\hline & & & & & -5.03 & & & & & & & & & & & \\
\hline \multirow[t]{2}{*}{ Dispersion [lifecycle expertise] } & & & & & & & -0.873 & $* * *$ & & & & & & & & \\
\hline & & & & & & & -5.08 & & & & & & & & & \\
\hline \multirow[t]{2}{*}{ Dispersion index [expertise] } & & & & & & & & & -1.380 & *** & & & & & & \\
\hline & & & & & & & & & -6.24 & & & & & & & \\
\hline \multirow[t]{2}{*}{ Dispersion [board seats] } & & & & & & & & & & & -1.372 & & & & & \\
\hline & & & & & & & & & & & -4.28 & & & & & \\
\hline \multirow[t]{2}{*}{ Dispersion [ownership] } & & & & & & & & & & & & & -0.777 & ${ }^{* * * *}$ & & \\
\hline & & & & & & & & & & & & & -3.20 & & & \\
\hline \multirow[t]{2}{*}{ Dispersion index [expertise \& incentives] } & & & & & & & & & & & & & & & -2.669 & ${ }^{* * *}$ \\
\hline & & & & & & & & & & & & & & & -5.24 & \\
\hline \multirow[t]{2}{*}{ Firm size } & 0.322 & $* * *$ & 0.246 & $* * *$ & 0.267 & $* * *$ & 0.262 & $* * *$ & 0.289 & $* * *$ & 0.248 & $* * *$ & 0.244 & $* * *$ & 0.309 & ${ }^{* * *}$ \\
\hline & 4.60 & & 3.84 & & 4.08 & & 4.01 & & 4.30 & & 3.93 & & 3.75 & & 4.29 & \\
\hline \multirow[t]{2}{*}{ Firm age } & -0.261 & $* * *$ & -0.278 & $* * *$ & -0.274 & $* * *$ & -0.283 & $* * *$ & -0.275 & $* * *$ & -0.251 & $* * *$ & -0.257 & *** & -0.233 & ${ }^{* * *}$ \\
\hline & -4.00 & & -4.08 & & -4.06 & & -4.16 & & -4.08 & & -3.75 & & -3.94 & & -3.70 & \\
\hline \multirow[t]{2}{*}{ Sales growth } & 0.235 & & 0.336 & $* *$ & 0.297 & * & 0.311 & $*$ & 0.278 & * & 0.348 & $* *$ & 0.301 & $*$ & 0.223 & \\
\hline & 1.49 & & 2.06 & & 1.87 & & 1.94 & & 1.72 & & 2.15 & & 1.87 & & 1.40 & \\
\hline \multirow[t]{2}{*}{ Cash flow } & 1.584 & $* * *$ & 1.545 & $* * *$ & 1.598 & $* * *$ & 1.505 & $* * *$ & 1.649 & $* * *$ & 1.481 & $* * *$ & 1.528 & $* * *$ & 1.564 & *** \\
\hline & 3.71 & & 3.48 & & 3.52 & & 3.50 & & 3.66 & & 3.42 & & 3.55 & & 3.70 & \\
\hline \multirow[t]{2}{*}{ Tangible assets } & -0.140 & & -0.307 & & -0.297 & & -0.244 & & -0.272 & & -0.303 & & -0.176 & & -0.122 & \\
\hline & -0.38 & & -0.80 & & -0.78 & & -0.64 & & -0.72 & & -0.80 & & -0.46 & & -0.33 & \\
\hline
\end{tabular}




\begin{tabular}{|c|c|c|c|c|c|c|c|c|}
\hline \multirow[t]{2}{*}{ CEO tenure } & 0.066 & $0.090^{*}$ & $0.077^{*}$ & $0.083^{*}$ & 0.070 & $0.085^{*}$ & $0.096^{* *}$ & 0.070 \\
\hline & 1.47 & 1.91 & 1.65 & 1.80 & 1.53 & 1.80 & 2.05 & 1.61 \\
\hline \multirow[t]{2}{*}{ Business segments } & $-0.303^{* * *}$ & $-0.339^{* * *}$ & $-0.332^{* * *}$ & $-0.338^{* * *}$ & $-0.327^{* * *}$ & $-0.346^{* * *}$ & $-0.328^{* * *}$ & $-0.304^{* * *}$ \\
\hline & -4.26 & -4.59 & -4.52 & -4.60 & -4.49 & -4.75 & -4.45 & -4.22 \\
\hline \multirow[t]{2}{*}{ Foreign segment } & -0.088 & -0.176 & -0.161 & -0.156 & -0.146 & -0.166 & -0.188 & -0.140 \\
\hline & -0.52 & -1.04 & -0.95 & -0.92 & -0.86 & -0.99 & -1.14 & -0.85 \\
\hline \multirow[t]{2}{*}{ High tech } & -0.365 & -0.229 & -0.273 & -0.223 & -0.278 & -0.246 & -0.191 & -0.290 \\
\hline & -1.37 & -0.85 & -1.02 & -0.84 & -1.04 & -0.92 & -0.71 & -1.08 \\
\hline \multirow[t]{2}{*}{ Industry concentration } & -1.087 & -1.063 & -1.119 & -1.273 & -1.086 & -1.028 & -0.887 & -0.666 \\
\hline & -1.19 & -1.15 & -1.21 & -1.37 & -1.17 & -1.14 & -0.96 & -0.74 \\
\hline Obs. & 3205 & 3175 & 3172 & 3176 & 3171 & 3205 & 3205 & 3205 \\
\hline $\mathrm{R}^{2}$ & 0.26 & 0.24 & 0.24 & 0.24 & 0.25 & 0.24 & 0.24 & 0.27 \\
\hline
\end{tabular}


Panel C: Other measures of dispersion in director expertise and incentives

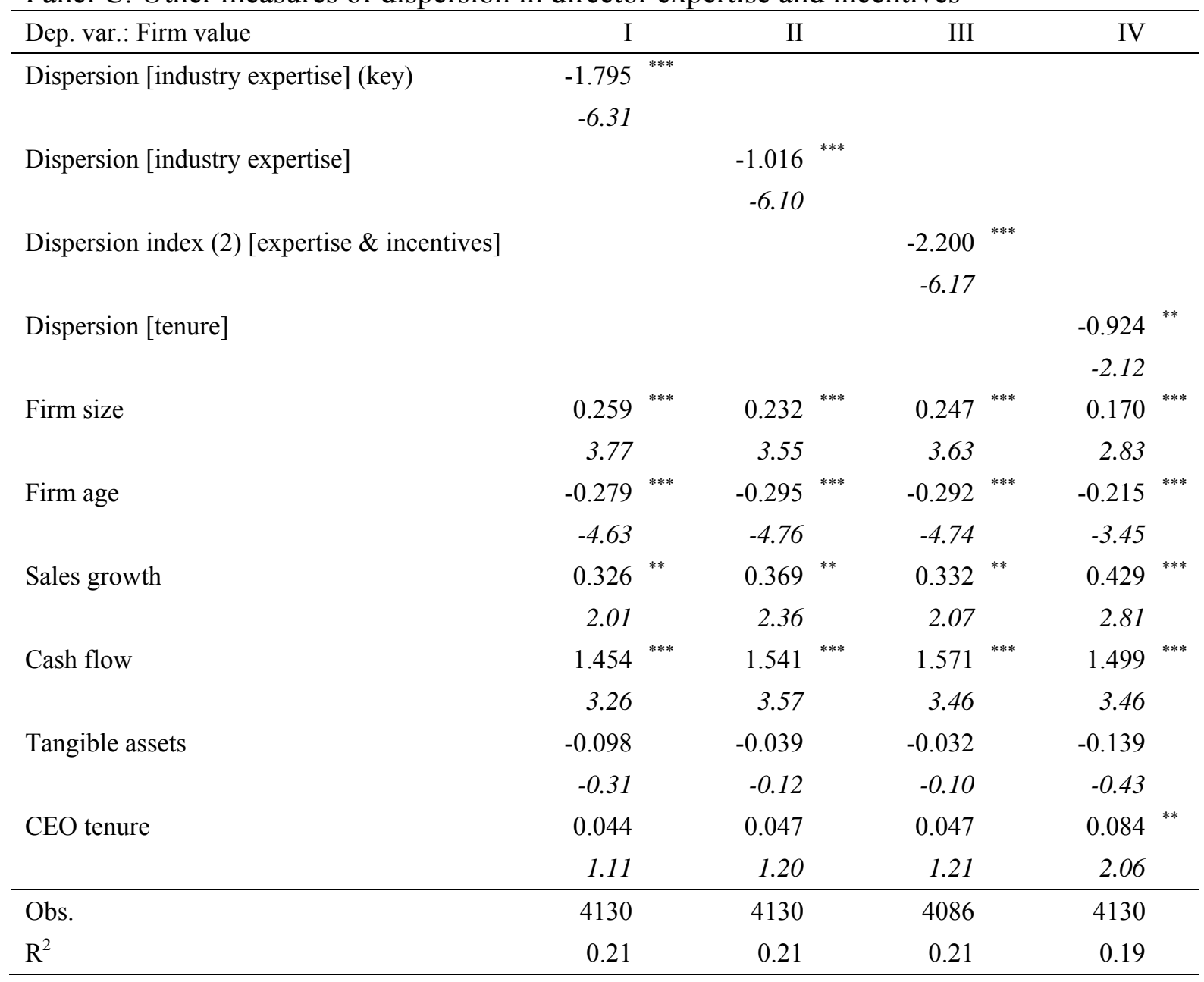


Panel D: Interactions of board dispersion and cash flow

\begin{tabular}{|c|c|c|c|c|c|c|c|c|c|c|c|c|c|c|c|c|}
\hline Dep. var.: Firm value & I & & II & & III & & IV & & $\mathrm{V}$ & & VI & & VII & & VIII & \\
\hline \multirow[t]{2}{*}{ Dispersion [industry expertise] } & -1.348 & *** & & & & & & & & & & & & & & \\
\hline & -6.140 & & & & & & & & & & & & & & & \\
\hline \multirow[t]{2}{*}{ Dispersion [size expertise] } & & & -0.507 & $* * *$ & & & & & & & & & & & & \\
\hline & & & -3.22 & & & & & & & & & & & & & \\
\hline \multirow[t]{2}{*}{ Dispersion [risk expertise] } & & & & & -0.685 & $* * *$ & & & & & & & & & & \\
\hline & & & & & -3.70 & & & & & & & & & & & \\
\hline \multirow[t]{2}{*}{ Dispersion [lifecycle expertise] } & & & & & & & -0.858 & $* * *$ & & & & & & & & \\
\hline & & & & & & & -5.63 & & & & & & & & & \\
\hline \multirow[t]{2}{*}{ Dispersion index [expertise] } & & & & & & & & & -1.332 & & & & & & & \\
\hline & & & & & & & & & -5.51 & & & & & & & \\
\hline \multirow[t]{2}{*}{ Dispersion [board seats] } & & & & & & & & & & & -1.083 & & & & & \\
\hline & & & & & & & & & & & -3.95 & & & & & \\
\hline \multirow[t]{2}{*}{ Dispersion [ownership] } & & & & & & & & & & & & & -0.539 & $* * *$ & & \\
\hline & & & & & & & & & & & & & -3.49 & & & \\
\hline Dispersion index & & & & & & & & & & & & & & & -2.175 & $* * *$ \\
\hline [expertise \& incentives] & & & & & & & & & & & & & & & -6.55 & \\
\hline \multirow[t]{2}{*}{ Dispersion measure*Cash flow } & 2.025 & $* *$ & 0.578 & & -0.025 & & 1.753 & $*$ & 2.256 & * & -2.846 & & 1.316 & & 3.617 & $*$ \\
\hline & 2.32 & & 0.46 & & -0.02 & & 1.81 & & 1.74 & & -0.79 & & 0.86 & & 1.69 & \\
\hline \multirow[t]{2}{*}{ Firm size } & 0.192 & $* * *$ & 0.126 & $* *$ & 0.148 & $* * *$ & 0.139 & $* * *$ & 0.165 & *** & 0.134 & $* * *$ & 0.122 & $* *$ & 0.178 & $* * *$ \\
\hline & 3.53 & & 2.57 & & 2.81 & & 2.86 & & 3.13 & & 2.89 & & 2.54 & & 3.43 & \\
\hline \multirow[t]{2}{*}{ Firm age } & -0.247 & $* * *$ & -0.267 & $* * *$ & -0.258 & $* * *$ & -0.270 & $* * *$ & -0.260 & $* * *$ & -0.251 & $* * *$ & -0.253 & $* * *$ & -0.231 & $* * *$ \\
\hline & -4.46 & & -4.61 & & -4.55 & & -4.67 & & -4.57 & & -4.38 & & -4.45 & & -4.19 & \\
\hline \multirow[t]{2}{*}{ Sales growth } & 0.351 & $* *$ & 0.412 & $* *$ & 0.407 & $* *$ & 0.406 & $* *$ & 0.386 & $* *$ & 0.422 & $* * *$ & 0.381 & $* *$ & 0.332 & $* *$ \\
\hline & 2.04 & & 2.49 & & 2.42 & & 2.47 & & 2.23 & & 2.63 & & 2.48 & & 2.1 & \\
\hline \multirow[t]{2}{*}{ Cash flow } & 1.115 & $* *$ & 1.889 & $* * *$ & 2.228 & $* * *$ & 1.328 & $* *$ & 1.100 & & 3.912 & * & 1.604 & $* *$ & 0.246 & \\
\hline & 2.08 & & 2.58 & & 3.11 & & 2.1 & & 1.41 & & 1.67 & & 2.07 & & 0.21 & \\
\hline
\end{tabular}




\begin{tabular}{|c|c|c|c|c|c|c|c|c|c|c|c|c|c|c|}
\hline Tangible assets & $-0.695^{* * *}$ & -0.673 & $* * *$ & -0.660 & $* * *$ & -0.681 & $* * *$ & -0.674 & $* * *$ & -0.656 & $* * *$ & -0.654 & $* * *$ & -0.670 \\
\hline \multirow{3}{*}{ CEO tenure } & -3.08 & -2.96 & & -2.93 & & -2.97 & & -2.99 & & -2.89 & & -2.88 & & -2.96 \\
\hline & 0.057 & 0.081 & $* *$ & 0.067 & $*$ & 0.076 & $*$ & 0.063 & & 0.076 & * & 0.086 & $* *$ & 0.063 \\
\hline & 1.46 & 2.02 & & 1.66 & & 1.92 & & 1.58 & & 1.91 & & 2.19 & & 1.64 \\
\hline Obs. & 4130 & 4091 & & 4087 & & 4092 & & 4086 & & 4130 & & 4130 & & 4130 \\
\hline $\mathrm{R}^{2}$ & 0.19 & 0.17 & & 0.17 & & 0.17 & & 0.18 & & 0.17 & & 0.17 & & 0.19 \\
\hline
\end{tabular}


Table 6. Robustness tests: other firm outcomes

Sample and variable definitions are shown in Table 1 and the Appendix. Regressions of firm outcomes on board dispersion, controls, three-digit SIC industry effects, and year effects. Robust t-statistics clustered by firm are italicized. Significance at $1 \%, 5 \%$, and $10 \%$ is denoted with ${ }^{* * *},{ }^{* *}$, and ${ }^{*}$. Return is the average monthly excess return obtained from CRSP.

Panel A: CEO compensation

\begin{tabular}{|c|c|c|c|c|c|c|c|c|}
\hline & \multirow{2}{*}{\multicolumn{2}{|c|}{$\begin{array}{c}\text { CEO } \\
\text { total pay } \\
\text { I }\end{array}$}} & \multicolumn{2}{|l|}{$\begin{array}{c}\text { CEO } \\
\text { cash pay }\end{array}$} & \multicolumn{2}{|c|}{$\begin{array}{c}\text { CEO } \\
\text { incentive/ } \\
\text { total pay }\end{array}$} & \multicolumn{2}{|l|}{$\begin{array}{l}\text { CEO } \\
\text { turnover }\end{array}$} \\
\hline & & & II & & III & & IV & \\
\hline Dispersion index & 0.720 & *** & 0.742 & *** & -0.076 & * & -0.107 & *** \\
\hline [expertise \& incentives] & 4.71 & & 4.84 & & -1.65 & & -2.83 & \\
\hline \multirow[t]{2}{*}{ Firm size } & 0.400 & $* * *$ & 0.215 & *** & 0.028 & *** & -0.009 & ** \\
\hline & 18.35 & & 7.72 & & 4.96 & & -2.13 & \\
\hline \multirow[t]{2}{*}{ Firm age } & 0.032 & & 0.113 & $* * *$ & -0.018 & ** & 0.011 & * \\
\hline & 1.15 & & 3.38 & & -2.22 & & 1.85 & \\
\hline \multirow[t]{2}{*}{ Sales growth } & 0.063 & & 0.109 & * & 0.002 & & -0.002 & \\
\hline & 1.02 & & 1.71 & & 0.07 & & -0.12 & \\
\hline \multirow[t]{2}{*}{ Cash flow } & 0.411 & ${ }^{* *}$ & 0.451 & ** & 0.101 & ** & 0.023 & \\
\hline & 2.36 & & 2.07 & & 1.98 & & 0.57 & \\
\hline \multirow[t]{2}{*}{ Tangible assets } & -0.598 & ${ }^{* * *}$ & -0.081 & & -0.108 & * & -0.025 & \\
\hline & -3.46 & & -0.51 & & -1.89 & & -0.54 & \\
\hline \multirow[t]{2}{*}{ CEO tenure } & -0.033 & & 0.016 & & -0.022 & *** & -0.228 & \\
\hline & -1.51 & & 0.82 & & -3.35 & & -32.05 & \\
\hline \multirow[t]{2}{*}{ Return } & -0.758 & & 1.534 & *** & -0.945 & ${ }^{* * *}$ & -0.016 & \\
\hline & -1.44 & & 3.03 & & -6.06 & & -0.10 & \\
\hline Obs. & 4013 & & 4013 & & 4009 & & 3950 & \\
\hline $\mathrm{R}^{2}$ & 0.46 & & 0.38 & & 0.26 & & 0.36 & \\
\hline
\end{tabular}


Panel B: Financial and investment decisions

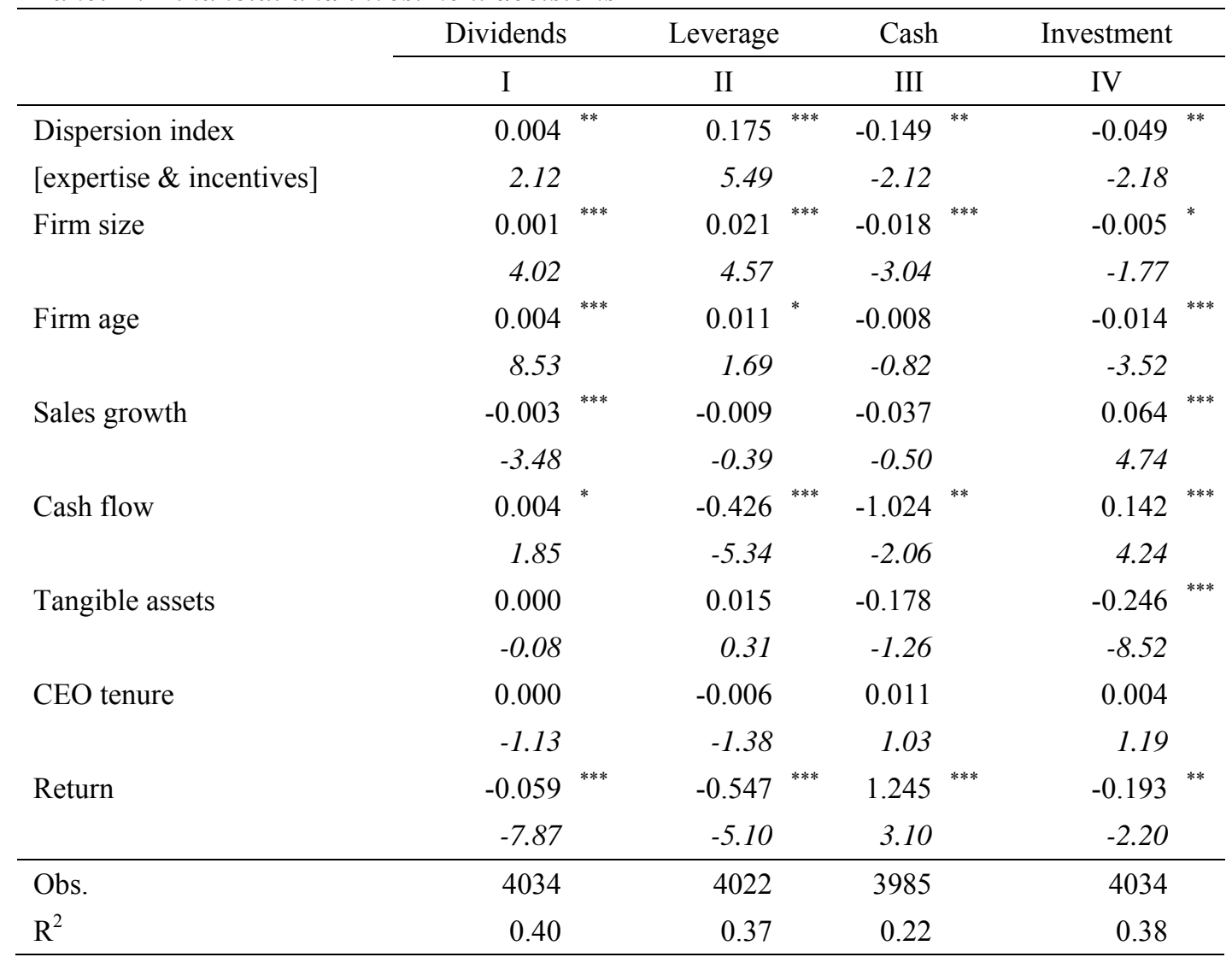


Table 7. Determinants of board dispersion

Sample and variable definitions are shown in Table 1 and the Appendix. Regressions of board dispersion on explanatory variables, three-digit SIC industry effects, and year effects. The economic magnitude of the effect is defined as the change in dispersion, expressed as a percentage of standard deviation of dispersion, in response to a one standard deviation change in the explanatory variable (an increase from 0 to 1 if the variable is binary), all else equal. Robust tstatistics clustered by firm are italicized. Significance at $1 \%, 5 \%$, and $10 \%$ is denoted with ${ }^{* * *},{ }^{* *}$, and ${ }^{*}$.

\begin{tabular}{|c|c|c|c|c|c|c|c|c|c|c|c|c|c|c|c|c|}
\hline \multirow[t]{2}{*}{ Dep. var. - Dispersion: } & \multicolumn{2}{|c|}{$\begin{array}{l}\text { [industry } \\
\text { expertise] }\end{array}$} & \multicolumn{2}{|c|}{$\begin{array}{c}\text { [size } \\
\text { expertise] }\end{array}$} & \multicolumn{2}{|c|}{$\begin{array}{c}{[\text { risk }} \\
\text { expertise] }\end{array}$} & \multicolumn{2}{|c|}{$\begin{array}{l}\text { [lifecycle } \\
\text { expertise] }\end{array}$} & \multicolumn{2}{|c|}{$\begin{array}{c}\text { index } \\
\text { [expertise] }\end{array}$} & \multicolumn{2}{|c|}{$\begin{array}{l}\text { [board } \\
\text { seats] }\end{array}$} & \multicolumn{2}{|c|}{ [ownership] } & \multicolumn{2}{|c|}{$\begin{array}{c}\text { index } \\
\text { [expertise \& } \\
\text { incentives] }\end{array}$} \\
\hline & $\mathrm{I}$ & & II & & III & & IV & & $\mathrm{V}$ & & VI & & VII & & VIII & \\
\hline \multirow[t]{2}{*}{ Firm size } & 0.054 & ${ }^{* * *}$ & 0.022 & *** & 0.045 & 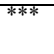 & 0.030 & *** & 0.036 & ${ }^{* * * *}$ & 0.013 & **** & 0.015 & **** & 0.029 & *** \\
\hline & 15.08 & & 6.16 & & 13.93 & & 9.14 & & 12.80 & & 8.78 & & 2.82 & & 12.50 & \\
\hline \multirow[t]{2}{*}{ Firm age } & 0.016 & $* * *$ & -0.003 & & 0.009 & * & -0.004 & & 0.003 & & 0.009 & *** & 0.022 & $* * *$ & 0.007 & $* *$ \\
\hline & 2.91 & & -0.56 & & 1.68 & & -0.85 & & 0.80 & & 3.48 & & 2.77 & & 2.00 & \\
\hline \multirow[t]{2}{*}{ Sales growth } & -0.079 & $* * *$ & -0.039 & $* *$ & -0.050 & *** & -0.047 & $* * *$ & -0.054 & $* * *$ & 0.000 & & -0.070 & $* * *$ & -0.048 & $* * *$ \\
\hline & -4.11 & & -2.29 & & -2.81 & & -2.95 & & -3.63 & & 0.01 & & -3.74 & & -4.33 & \\
\hline \multirow[t]{2}{*}{ Cash flow } & 0.041 & & 0.036 & & -0.029 & & 0.013 & & 0.007 & & -0.033 & ** & 0.030 & & 0.000 & \\
\hline & 0.98 & & 0.91 & & -0.70 & & 0.36 & & 0.23 & & -2.00 & & 0.67 & & -0.02 & \\
\hline \multirow[t]{2}{*}{ CEO tenure } & -0.020 & $* * *$ & -0.016 & $* * *$ & -0.028 & *** & -0.013 & $* *$ & -0.019 & $* * *$ & -0.007 & *** & -0.002 & & -0.014 & $* * *$ \\
\hline & -4.18 & & -3.12 & & -5.66 & & -2.56 & & -4.63 & & -3.05 & & -0.35 & & -4.44 & \\
\hline \multirow[t]{2}{*}{ Local availability of directors } & -0.013 & *** & -0.004 & & -0.002 & & 0.002 & & -0.003 & & 0.000 & & -0.007 & & -0.003 & \\
\hline & -3.33 & & -0.98 & & -0.50 & & 0.66 & & -0.90 & & 0.23 & & -1.47 & & -1.14 & \\
\hline \multirow[t]{2}{*}{ Dispersion in the industry } & 0.469 & $* * *$ & 0.555 & $* * *$ & 0.490 & *** & 0.538 & $* * *$ & 0.517 & *** & 0.422 & *** & 0.634 & & 0.530 & $* * *$ \\
\hline & 10.39 & & 12.74 & & 14.32 & & 13.28 & & 14.64 & & 11.20 & & 15.27 & & 15.94 & \\
\hline \multirow[t]{2}{*}{ Post-SOX } & 0.026 & $* * *$ & 0.013 & $*$ & 0.013 & * & 0.011 & & 0.015 & $* * *$ & 0.014 & *** & 0.010 & & 0.015 & *** \\
\hline & 4.20 & & 1.75 & & 1.86 & & 1.62 & & 2.89 & & 3.90 & & 1.35 & & 3.63 & \\
\hline Obs. & 4136 & & 4097 & & 4093 & & 4098 & & 4092 & & 4136 & & 4136 & & 4092 & \\
\hline $\mathrm{R}^{2}$ & 0.27 & & 0.13 & & 0.22 & & 0.15 & & 0.25 & & 0.13 & & 0.15 & & 0.27 & \\
\hline
\end{tabular}




\section{Economic magnitudes}

\begin{tabular}{|c|c|c|c|c|c|c|c|c|c|c|c|c|c|c|c|c|}
\hline Firm size & $71 \%$ & *** & $28 \%$ & $* * *$ & $48 \%$ & $* * *$ & $36 \%$ & *** & $48 \%$ & $* * *$ & $34 \%$ & $* * *$ & $15 \%$ & $* * *$ & $47 \%$ & $* * *$ \\
\hline Firm age & $13 \%$ & $* * *$ & $-2 \%$ & & $6 \%$ & & $-3 \%$ & & $3 \%$ & & $14 \%$ & & $13 \%$ & & $7 \%$ & \\
\hline Sales growth & $-17 \%$ & $* * *$ & $-8 \%$ & $* *$ & $-8 \%$ & ** & $-9 \%$ & $* *$ & $-11 \%$ & ** & $0 \%$ & ** & $-11 \%$ & ** & $-12 \%$ & ** \\
\hline Cash flow & $4 \%$ & & $4 \%$ & & $-3 \%$ & & $1 \%$ & & $1 \%$ & & $-7 \%$ & & $2 \%$ & & $0 \%$ & \\
\hline CEO tenure & $-16 \%$ & $* * *$ & $-12 \%$ & $* * *$ & $-18 \%$ & $* * *$ & $-10 \%$ & $* * *$ & $-15 \%$ & $* * *$ & $-11 \%$ & *** & $-1 \%$ & *** & $-14 \%$ & $* * *$ \\
\hline Local availability of directors & $-17 \%$ & $* * *$ & $-5 \%$ & & $-2 \%$ & & $3 \%$ & & $-4 \%$ & & $1 \%$ & & $-7 \%$ & & $-4 \%$ & \\
\hline Dispersion in the industry & $97 \%$ & $* * *$ & $108 \%$ & $* * *$ & $83 \%$ & $* * *$ & $95 \%$ & $* * *$ & $86 \%$ & $* * *$ & $79 \%$ & *** & $120 \%$ & $* * *$ & $87 \%$ & *** \\
\hline Post-SOX & $24 \%$ & $* * *$ & $12 \%$ & * & $10 \%$ & * & $9 \%$ & & $14 \%$ & $* * *$ & $25 \%$ & $* * *$ & $7 \%$ & & $17 \%$ & *** \\
\hline
\end{tabular}


Table 8. Two-stage least squares estimation of board dispersion effects on value

Sample and variable definitions are shown in Table 1 and the Appendix. Two-stage least squares regressions of market-to-book on board dispersion, controls, three-digit SIC industry effects, and year effects. Board dispersion is predicted with industry median, local availability of directors, and post-SOX indicator. The economic magnitude of the effect is defined as the change in market-to-book, in standard deviation times (times $100 \%$ ), in response to a one standard deviation change in the explanatory variable, all else equal. Robust t-statistics clustered by firm are italicized. Significance at $1 \%, 5 \%$, and $10 \%$ is denoted with ${ }^{* * * * *}$, and .

\begin{tabular}{|c|c|c|c|c|c|c|c|c|c|c|c|c|c|c|c|c|}
\hline Dep. var.: Firm value & $\mathrm{I}$ & & II & & III & & IV & & $\mathrm{V}$ & & VI & & VII & & VIII & \\
\hline \multirow[t]{2}{*}{ Dispersion [industry expertise] } & -4.418 & $* * *$ & & & & & & & & & & & & & & \\
\hline & -3.47 & & & & & & & & & & & & & & & \\
\hline \multirow[t]{2}{*}{ Dispersion [size expertise] } & & & -0.950 & * & & & & & & & & & & & & \\
\hline & & & -1.79 & & & & & & & & & & & & & \\
\hline \multirow[t]{2}{*}{ Dispersion [risk expertise] } & & & & & -1.714 & *** & & & & & & & & & & \\
\hline & & & & & -3.38 & & & & & & & & & & & \\
\hline \multirow[t]{2}{*}{ Dispersion [lifecycle expertise] } & & & & & & & -1.006 & $* *$ & & & & & & & & \\
\hline & & & & & & & -2.21 & & & & & & & & & \\
\hline \multirow[t]{2}{*}{ Dispersion index [expertise] } & & & & & & & & & -3.131 & $* * *$ & & & & & & \\
\hline & & & & & & & & & -4.25 & & & & & & & \\
\hline \multirow[t]{2}{*}{ Dispersion [board seats] } & & & & & & & & & & & -1.186 & & & & & \\
\hline & & & & & & & & & & & -1.52 & & & & & \\
\hline \multirow[t]{2}{*}{ Dispersion [ownership] } & & & & & & & & & & & & & -0.848 & ** & & \\
\hline & & & & & & & & & & & & & -2.13 & & & \\
\hline Dispersion index & & & & & & & & & & & & & & & -3.366 & $* * *$ \\
\hline [expertise \& incentives] & & & & & & & & & & & & & & & -4.02 & \\
\hline \multirow[t]{2}{*}{ Firm size } & 0.446 & $* * *$ & 0.195 & $* * *$ & 0.259 & $* * *$ & 0.208 & $* * *$ & 0.310 & $* * *$ & 0.183 & $* * *$ & 0.181 & $* * *$ & 0.288 & $* * *$ \\
\hline & 4.23 & & 3.25 & & 4.03 & & 3.36 & & 4.58 & & 2.90 & & 3.03 & & 4.57 & \\
\hline \multirow[t]{2}{*}{ Firm age } & -0.242 & $* * *$ & -0.315 & $* * *$ & -0.293 & $* * *$ & -0.318 & $* * *$ & -0.299 & $* * *$ & -0.294 & $* * *$ & -0.288 & $* * *$ & -0.282 & $* * *$ \\
\hline & -3.87 & & -4.92 & & -4.61 & & -5.01 & & -4.70 & & -4.76 & & -4.64 & & -4.45 & \\
\hline \multirow[t]{2}{*}{ Sales growth } & 0.156 & & 0.381 & $* *$ & 0.348 & $* *$ & 0.381 & $* *$ & 0.285 & $*$ & 0.417 & $* * *$ & 0.363 & $* *$ & 0.287 & $*$ \\
\hline & 0.83 & & 2.43 & & 2.16 & & 2.48 & & 1.72 & & 2.74 & & 2.35 & & 1.76 & \\
\hline
\end{tabular}




\begin{tabular}{|c|c|c|c|c|c|c|c|c|c|c|c|c|c|c|c|c|}
\hline \multirow[t]{2}{*}{ Cash flow } & 1.650 & ${ }^{* * *}$ & 1.546 & ${ }^{* * *}$ & 1.498 & ${ }^{* * *}$ & 1.501 & ${ }^{* * *}$ & 1.554 & ${ }^{* * *}$ & 1.499 & ${ }^{* * *}$ & 1.561 & ${ }^{* * *}$ & 1.557 & ${ }^{* * *}$ \\
\hline & 3.53 & & 3.46 & & 3.16 & & 3.47 & & 3.32 & & 3.45 & & 3.61 & & 3.40 & \\
\hline \multirow[t]{2}{*}{ Tangible assets } & 0.043 & & -0.086 & & -0.041 & & -0.064 & & -0.006 & & -0.156 & & -0.021 & & 0.018 & \\
\hline & 0.13 & & -0.26 & & -0.13 & & -0.20 & & -0.02 & & -0.49 & & -0.06 & & 0.06 & \\
\hline \multirow[t]{2}{*}{ CEO tenure } & -0.009 & & 0.064 & & 0.027 & & 0.065 & & 0.016 & & 0.067 & & 0.075 & * & 0.029 & \\
\hline & -0.19 & & 1.53 & & 0.62 & & 1.60 & & 0.37 & & 1.64 & & 1.84 & & 0.69 & \\
\hline Obs. & 4130 & & 4091 & & 4087 & & 4092 & & 4086 & & 4130 & & 4130 & & 4086 & \\
\hline $\mathrm{R}^{2}$ & 0.12 & & 0.19 & & 0.19 & & 0.20 & & 0.18 & & 0.19 & & 0.20 & & 0.21 & \\
\hline
\end{tabular}

\begin{tabular}{|c|c|c|c|c|c|c|c|c|c|c|c|c|c|c|c|c|}
\hline Economic magnitudes of the effects & I & & II & & III & & IV & & $\mathrm{V}$ & & VI & & VII & & VIII & \\
\hline Dispersion [industry expertise] & $-58.2 \%$ & ${ }^{* * *}$ & & & & & & & & & & & & & & \\
\hline Dispersion [size expertise] & & & $-12.1 \%$ & * & & & & & & & & & & & & \\
\hline Dispersion [risk expertise] & & & & & $-23.1 \%$ & ${ }^{* * *}$ & & & & & & & & & & \\
\hline Dispersion [lifecycle expertise] & & & & & & & $-12.7 \%$ & ${ }^{* *}$ & & & & & & & & \\
\hline Dispersion index [expertise] & & & & & & & & & $-33.7 \%$ & ${ }^{* * *}$ & & & & & & \\
\hline Dispersion [board seats] & & & & & & & & & & & $-7.4 \%$ & & & & & \\
\hline Dispersion [ownership] & & & & & & & & & & & & & $-5.3 \%$ & ** & & \\
\hline $\begin{array}{l}\text { Dispersion index } \\
\text { [expertise \& incentives] }\end{array}$ & & & & & & & & & & & & & & & $-33.3 \%$ & *** \\
\hline Firm size & $37.5 \%$ & ${ }^{* * *}$ & $16.4 \%$ & $* * *$ & $21.8 \%$ & ${ }^{* * *}$ & $17.5 \%$ & ${ }^{* * *}$ & $26.1 \%$ & ${ }^{* * *}$ & $15.4 \%$ & ${ }^{* * *}$ & $15.2 \%$ & *** & $24.7 \%$ & ${ }^{* * *}$ \\
\hline Firm age & $-12.6 \%$ & ${ }^{* * *}$ & $-16.4 \%$ & ${ }^{* * *}$ & $-15.3 \%$ & ${ }^{* * *}$ & $-16.5 \%$ & $* * *$ & $-15.5 \%$ & ${ }^{* * *}$ & $-15.3 \%$ & ${ }^{* * *}$ & $-15.0 \%$ & ${ }^{* * *}$ & $-12.5 \%$ & ${ }^{* * *}$ \\
\hline Sales growth & $2.1 \%$ & & $5.1 \%$ & ** & $4.7 \%$ & ${ }^{* *}$ & $5.1 \%$ & ${ }^{* *}$ & $3.8 \%$ & * & $5.6 \%$ & ${ }^{* * *}$ & $4.9 \%$ & ** & $3.4 \%$ & \\
\hline Cash flow & $11.6 \%$ & ${ }^{* * *}$ & $10.8 \%$ & ${ }^{* * *}$ & $10.5 \%$ & ${ }^{* * *}$ & $10.5 \%$ & $* * *$ & $10.9 \%$ & ${ }^{* * *}$ & $10.5 \%$ & ${ }^{* * *}$ & $10.9 \%$ & ${ }^{* * *}$ & $11.0 \%$ & *** \\
\hline Tangible assets & $0.5 \%$ & & $-1.1 \%$ & & $-0.5 \%$ & & $-0.8 \%$ & & $-0.1 \%$ & & $-1.9 \%$ & & $-0.3 \%$ & & $0.4 \%$ & \\
\hline CEO tenure & $-0.5 \%$ & & $3.3 \%$ & & $1.4 \%$ & & $3.3 \%$ & & $0.8 \%$ & & $3.4 \%$ & & $3.8 \%$ & * & $1.9 \%$ & \\
\hline
\end{tabular}




\section{Table 9. Board dispersion and shareholder wealth effects of M\&A announcements}

Sample and variable definitions are shown in Table 1 and the Appendix. Regressions of acquirer abnormal return on announcement. The sample consists of acquisition announcements from SDC Platinum made by public US acquirers with nonmissing Compustat, CDA Spectrum, and Board Analyst data for 2001-2006. Acquirers with total assets less than twenty million and bids for non-US targets are excluded. Average director expertise and incentives, as applicable, two-digit SIC industry effects, and year effects are included. Robust t-statistics clustered by firm are italicized. Significance at $1 \%, 5 \%$, and $10 \%$ is denoted with ${ }^{* * *},{ }^{* *}$, and ${ }^{*}$.

Panel A: Dispersion in industry expertise

\begin{tabular}{lrrrr}
\hline Dep. var.: Acquirer CAR & I & II & III \\
\hline Dispersion [industry expertise] & $-1.383^{* *}$ & $-1.480^{* *}$ & $-1.465^{* *}$ \\
& -2.12 & -2.07 & -2.05 & \\
Sales growth & $1.772^{* *}$ & $1.776^{* *}$ & $1.780^{* *}$ \\
& 2.22 & 2.21 & 2.21 \\
Acquirer size & & 0.048 & 0.042 \\
& & 0.23 & 0.20 \\
Relative deal size & & -0.796 & -0.665 \\
& & -0.43 & -0.37 \\
Diversifying acquisition & & & 0.352 \\
& & & 0.66 \\
Acquirer and target are tech & & & -0.419 \\
& & & -0.36 \\
\hline Obs. & 1041 & 1041 & 1041 \\
$\mathrm{R}^{2}$ & 0.08 & 0.08 & 0.08 \\
\hline
\end{tabular}


Panel B: Dispersion in board expertise: other measures and dimensions of expertise

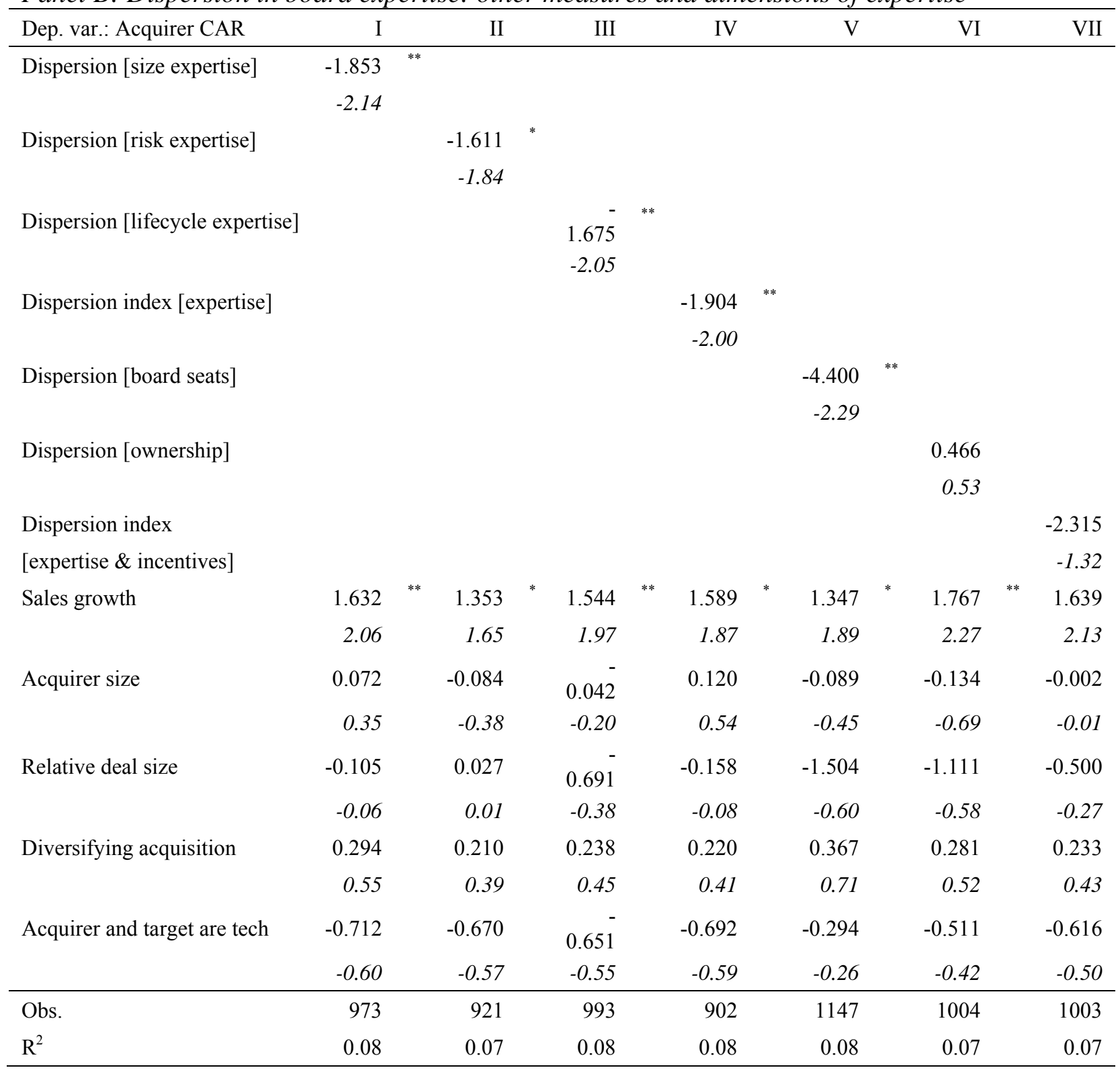




\section{Table 10. Market reaction to changes in board heterogeneity}

Sample and variable definitions are shown in Table 1 and the Appendix. Regressions of abnormal return on board announcement involving a change in director heterogeneity. The sample consists of companies that announced director appointments and departures that resulted in changes in director heterogeneity. Three-digit SIC industry effects and year effects are included where specified below. The sample of board announcements is constructed based on BoardEx data for 2003-2009 and includes relative changes in the index of heterogeneity of at least one percent as a result of one or more director appointments, departures, or replacements announced on a given date. Columns I-III use $\Delta$ Dispersion(qualifications). Columns IV-VI use $\Delta$ Dispersion(expertise). Robust t-statistics clustered by firm are italicized. Significance at $1 \%, 5 \%$, and $10 \%$ is denoted with ${ }^{* * *},{ }^{* *}$, and ${ }^{*}$.

\begin{tabular}{|c|c|c|c|c|c|c|c|c|c|}
\hline \multirow[t]{2}{*}{ Dependent var.: } & \multicolumn{6}{|c|}{ CAR(qualifications) } & \multicolumn{3}{|c|}{ CAR(expertise) } \\
\hline & I & & II & & III & & IV & $\mathrm{V}$ & VI \\
\hline \multirow[t]{2}{*}{$\Delta$ Dispersion } & 0.836 & & 0.953 & & 0.425 & & & & \\
\hline & 0.76 & & 0.86 & & 0.33 & & & & \\
\hline \multirow[t]{2}{*}{$\Delta$ Dispersion*Firm size } & -0.014 & & -0.030 & & -0.039 & & & & \\
\hline & -0.10 & & -0.21 & & -0.26 & & & & \\
\hline \multirow[t]{2}{*}{$\Delta$ Dispersion*Sales growth } & -1.549 & ** & -1.777 & ** & -1.756 & ${ }^{* *}$ & & & \\
\hline & -2.34 & & -2.40 & & -2.39 & & & & \\
\hline \multirow[t]{2}{*}{$\Delta$ Dispersion*Firm age } & & & & & 0.177 & & & & \\
\hline & & & & & 0.55 & & & & \\
\hline \multirow[t]{2}{*}{$\Delta$ Dispersion*High tech } & & & & & 0.361 & & & & \\
\hline & & & & & 0.61 & & & & \\
\hline \multirow[t]{2}{*}{$\Delta$ Outsiders } & & & & & 0.054 & & & & 0.779 \\
\hline & & & & & 0.08 & & & & 1.16 \\
\hline \multirow[t]{2}{*}{$\Delta$ Board size } & & & & & 0.097 & & & & 0.085 \\
\hline & & & & & 0.98 & & & & 0.82 \\
\hline \multirow[t]{2}{*}{$\Delta$ Qualifications } & & & & & -0.030 & & & & \\
\hline & & & & & -0.66 & & & & \\
\hline \multirow[t]{2}{*}{$\Delta$ Executive experts } & & & & & & & & & -0.047 \\
\hline & & & & & & & & & -0.42 \\
\hline Industry effects (SIC3) & NO & & YES & & YES & & NO & YES & YES \\
\hline Year effects & $\mathrm{NO}$ & & YES & & YES & & NO & YES & YES \\
\hline Obs. & 4085 & & 4085 & & 4085 & & 4387 & 4387 & 4387 \\
\hline $\mathrm{R}^{2}$ & 0.003 & & 0.047 & & 0.048 & & 0.002 & 0.046 & 0.047 \\
\hline
\end{tabular}


Appendix A. Board dispersion computation for a hypothetical firm

\begin{tabular}{|c|c|c|c|c|}
\hline Director & $\begin{array}{l}\text { has been } \\
\text { on the board for }\end{array}$ & $\begin{array}{l}\text { stake in } \\
\text { Firm A }\end{array}$ & also sits on the board of & $\begin{array}{l}\text { holds a total } \\
\text { of }\end{array}$ \\
\hline Director 1 & 3 years & $0 \%$ & Firm B [Apparel], Firm C [Soda] & 3 board seats \\
\hline Director 2 & 3 years & $0.5 \%$ & Firm D [Apparel] & 2 board seats \\
\hline Director 3 & 4 years & $1 \%$ & Firm E [Food] & 2 board seats \\
\hline Director 4 & 1 year & $0.5 \%$ & $\begin{array}{l}\text { Firm F [Pharm.], Firm G [Health care], } \\
\text { Firm H [Med. equip.] }\end{array}$ & 4 board seats \\
\hline Director 5 & 5 years & $2 \%$ & no other firms & 1 board seat \\
\hline Director 6 & 5 years & $0 \%$ & no other firms & 1 board seat \\
\hline
\end{tabular}

\section{Dispersion [industry expertise]}

Index defined as $1-\Sigma x_{k}^{2}$, where $x_{k}$ is the proportion of other board seats held by the firm's directors in Fama-French industry $k$; defined if the firm's board members as a group hold board seats at two or more other Board Analyst firms with nonmissing Compustat data; $x_{k}=n_{k} / n$, where $n_{k}$ is the number of other board seats held by the firm's directors in industry $k$ and $n$ is the overall number of other board seats (at Firms B-H) held by the firm's directors.

In our example, the firm's directors hold 7 board seats at outside firms in the following industries: "Food" (1 seat), "Soda" (1 seat), "Apparel" (2 seats), "Health care" (1 seat), "Medical equipment" (1 seat), and "Pharmaceuticals" (1 seat). Therefore:

Dispersion in industry expertise $=1-\Sigma x_{k}^{2}=1-\left[(1 / 7)^{2}+(1 / 7)^{2}+(2 / 7)^{2}+(1 / 7)^{2}+(1 / 7)^{2}+(1 / 7)^{2}\right]=1-0.18=0.82$

Dispersion in expertise along other dimensions is computed similarly.

\section{Dispersion [board seats]}

Index defined as $1-\Sigma d_{j}^{2}$, where $d_{j}$ is the proportion of directors with $j$ board seats among the firm's directors and $j$ assumes " 1 "... "5", or "above 5 ".

In the example above, the firm's board has 6 directors with the following board seat counts: "holds 1 seat" ( 2 directors), "holds 2 seats" ( 2 directors), "holds 3 seats" (1 director), "holds 4 seats" (1 director), "holds 5 seats" ( 0 directors $)$, "holders $>5$ seats" ( 0 directors $)$. Therefore:

Dispersion in board seats $=1-\Sigma d_{k j}^{2}=1-\left[(2 / 6)^{2}+(2 / 6)^{2}+(1 / 6)^{2}+(1 / 6)^{2}\right]=1-0.28=0.72$

\section{Dispersion [ownership]}

Index of dispersion of director ownership incentives, defined as $1-\sum s_{i}{ }^{2}$, where $s_{i}$ is the share of director $i$ 's ownership stake in total director ownership; defined if total director ownership is positive.

In the example above, $i=1 \ldots 6$ (six directors); individual director stakes are $0 \%, 0.5 \%, 1 \%, 0.5 \%, 2 \%$, and $0 \%$, respectively; as a group directors hold $(0+0.5+1+0.5+2+0)=4 \%$ in the firm.

Heterogeneity $($ director ownership $)=1-\Sigma s_{i}{ }^{2}=1-\left[(0 / 4)^{2}+(0.5 / 4)^{2}+(1 / 4)^{2}+(0.5 / 4)^{2}+(2 / 4)^{2}+(0 / 4)^{2}\right]=$ $1-0.34=0.66$

The above stylized example does not differentiate between outside and inside directors. Depending on the variation of the heterogeneity measure, we use Firm A's outside directors only; all of Firm A's directors besides the CEO, if present on the board; all of Firm A's directors (see variable definitions in Table 1). The computation is unchanged, except for the subset of board members used. 


\section{Appendix B. Sample and variable definitions and summary statistics}

The main sample uses US firms with nonmissing Compustat/CRSP data, excluding firms with total assets below 20 mln, financials (SIC 6000-6999), and regulated utilities (SIC 4900-4999). The sample is matched to Board Analyst data for 2001-2006. To ensure meaningful variation in board heterogeneity measures, members of the sample firm's board as a group are required to have appointments on the boards of two or more other firms with nonmissing data that can be matched to Compustat data and the sample firm's outside board members are required to have a positive total ownership stake in the sample firm. Certain controls require the availability of Execucomp data. The M\&A event study sample uses SDC Platinum data on bids by US acquirers with assets of at least 20 $\mathrm{mln}$, seeking at least a 10 percent stake in a US target, with deal values of at least $1 \mathrm{mln}$ and at least 1 percent of acquirer market value of equity, and nonmissing data on controls and announcement returns. The sample in Panel C uses the BoardEx board and director announcements file from March 2009, starting in 2003, matched to CRSP/Compustat. Boards with between three and forty directors are included. Changes of at least 1 percent due to director appointments, departures, or deaths are considered (multiple changes on the same date treated as one event). Other sample criteria are similar to Panel A.

\begin{tabular}{|c|c|c|c|c|c|}
\hline & Obs & Mean & Med & SD & Description \\
\hline \multicolumn{6}{|l|}{ Main variables } \\
\hline Market-to-book & 4130 & 1.38 & 0.95 & 1.65 & $\begin{array}{l}\text { Ratio of market value (book value of assets }+ \text { price } x \text { shares outstanding - book value of equity) to } \\
\text { total assets. }\end{array}$ \\
\hline Firm size & 4130 & 7.82 & 7.83 & 1.39 & Log of market value. ${ }^{\mathrm{d}}$ \\
\hline Firm age & 4130 & 2.93 & 2.97 & 0.86 & Log of number of years since first listing in CRSP; CRSP. \\
\hline Sales growth & 4130 & 0.10 & 0.08 & 0.22 & Annual change in net sales. ${ }^{\mathrm{d}}$ \\
\hline Cash flow & 4130 & 0.08 & 0.09 & 0.12 & Ratio of income before extraordinary items plus depreciation to total assets. ${ }^{\mathrm{d}}$ \\
\hline Tangible assets & 4130 & 0.27 & 0.21 & 0.20 & Ratio of net property, plants, and equipment to total assets; Compustat \\
\hline CEO tenure & 4130 & 1.66 & 1.61 & 0.85 & Log of one plus CEO tenure in the firm; Execucomp. \\
\hline \multicolumn{6}{|l|}{ Additional variables } \\
\hline Board size & 4130 & 2.33 & 2.30 & 0.30 & Log of the number of directors on the board. ${ }^{\mathrm{a}}$ \\
\hline Board independence & 4130 & 0.70 & 0.71 & 0.15 & Proportion of independent directors on the board. ${ }^{\text {a }}$ \\
\hline Business segments & 3532 & 0.86 & 1.10 & 0.70 & Log of the number of business segments; Compustat Segments. \\
\hline Foreign segment & 3798 & 0.82 & 1.00 & 0.38 & Equals 1 if the firm has a foreign segment; Compustat Segments. \\
\hline High tech & 4130 & 0.22 & 0.00 & 0.41 & Equals 1 if the firm's SIC industry is $2833-2836,3570-3577,3600-3674,7371-7379$ or $8731-8734 .^{\mathrm{d}}$ \\
\hline $\begin{array}{l}\text { Local availability of } \\
\text { directors }\end{array}$ & 4130 & 2.54 & 2.71 & 1.39 & $\begin{array}{l}\text { Log of one plus the number of US nonfinancial firms in the same or higher quartile of total assets } \\
\text { headquartered within sixty miles of the firm, excluding firms in the same four-digit SIC industry. }\end{array}$ \\
\hline Post-SOX & 4130 & 0.58 & 1.00 & 0.49 & Equals 1 for years after 2004, when SOX came into effect for the majority of firms. \\
\hline Industry concentration & 4130 & 0.17 & 0.13 & 0.12 & Herfindahl index based on sales in the firm's three-digit SIC industry. ${ }^{\mathrm{d}}$ \\
\hline CEO incentive/total pay & 4009 & 0.35 & 0.34 & 0.28 & Percent of CEO option grants in total CEO compensation including option grants; Execucomp. \\
\hline CEO cash pay & 4013 & 7.06 & 7.06 & 0.87 & Log of one plus CEO cash compensation; Execucomp. \\
\hline CEO total pay & 4013 & 8.20 & 8.22 & 1.00 & Log of one plus CEO total compensation; Execucomp. \\
\hline CEO turnover & 3950 & 0.11 & 0.00 & 0.31 & Indicator equal to 1 if CEO changed; 0 otherwise. Execucomp. \\
\hline
\end{tabular}




\begin{tabular}{|c|c|c|c|c|c|}
\hline Cash & 3985 & 0.15 & 0.07 & 0.39 & Ratio of cash to sales. ${ }^{\mathrm{d}}$ \\
\hline Leverage & 4022 & 0.23 & 0.20 & 0.19 & Ratio of the sum of long-term debt and debt in current liabilities to firm market value. ${ }^{\mathrm{d}}$ \\
\hline Investment & 4034 & 0.22 & 0.19 & 0.14 & Ratio of capital expenditure to tangible assets; replaced by zero if missing. ${ }^{\mathrm{d}}$ \\
\hline \multicolumn{6}{|l|}{ M\&A announcements ${ }^{f}$} \\
\hline Acquirer sales growth & 0.17 & 0.13 & 0.29 & 0.17 & Acquirer annual sales growth. ${ }^{\mathrm{d}, \mathrm{f}}$ \\
\hline Acquirer size & 6.88 & 6.82 & 1.31 & 6.88 & Log of acquirer sales. ${ }^{\mathrm{d} f}$ \\
\hline $\begin{array}{l}\text { Acquirer and target are } \\
\text { tech }\end{array}$ & 0.33 & 0.00 & 0.47 & 0.33 & Equals 1 if the acquirer and the target are both high tech firms (see above). ${ }^{\mathrm{f}}$ \\
\hline \multicolumn{6}{|l|}{ Board announcements $^{g}$} \\
\hline$\Delta$ Dispersion(qualifications) & 4042 & -0.03 & -0.02 & 0.22 & $\begin{array}{l}\text { Change in dispersion in outside director qualifications, scaled by the previous dispersion level. } \\
\text { Dispersion is defined as } 1-\Sigma q_{k}^{2} \text {, where } q_{k} \text { is the share of directors with } k(1,2,3,>3) \text { qualifications } \\
\text { among the firm's directors. }{ }^{\mathrm{g}}\end{array}$ \\
\hline CAR(expertise) & 4122 & -0.03 & -0.02 & 3.45 & Defined similarly, except based on $\Delta$ Dispersion (expertise). ${ }^{g}$ \\
\hline$\Delta$ Outsiders & 4789 & 0.00 & -0.02 & 0.09 & Change in the proportion of outsiders on the board, scaled by the previous proportion of outsiders. ${ }^{\mathrm{g}}$ \\
\hline$\Delta$ Board size & 4789 & -0.21 & -1.00 & 1.19 & Net number of directors joining or leaving the board as part of to the board change..$^{g}$ \\
\hline$\Delta$ Qualifications & 4789 & -0.62 & -1.00 & 2.56 & $\begin{array}{l}\text { Net increase or decrease in the number of professional or educational qualifications of outside } \\
\text { directors as a result of director appointments or departures from the board. }{ }^{\mathrm{g}}\end{array}$ \\
\hline$\Delta$ Executive experts & 4789 & -0.29 & -1.00 & 1.06 & $\begin{array}{l}\text { Net increase or decrease in the number of outside directors with executive expertise as a result of } \\
\text { addition or departure of directors from the board. }\end{array}$ \\
\hline 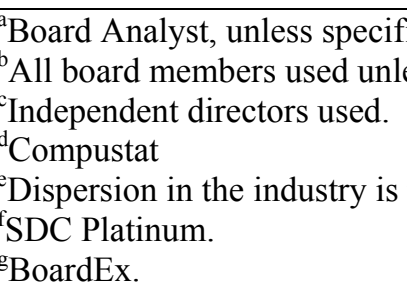 & ed othe & wise. $\mathrm{H}$ & gher val & es refl & ct more dispersion. \\
\hline
\end{tabular}

